\title{
The Crucible of Globalization: Latin America in the General Agreement on Tariffs and Trade 1973-1994
}

\author{
Madison Sergent
}

Follow this and additional works at: https://researchrepository.wvu.edu/etd

\section{Recommended Citation}

Sergent, Madison, "The Crucible of Globalization: Latin America in the General Agreement on Tariffs and Trade 1973-1994" (2016). Graduate Theses, Dissertations, and Problem Reports. 6602.

https://researchrepository.wvu.edu/etd/6602

This Thesis is protected by copyright and/or related rights. It has been brought to you by the The Research Repository @ WVU with permission from the rights-holder(s). You are free to use this Thesis in any way that is permitted by the copyright and related rights legislation that applies to your use. For other uses you must obtain permission from the rights-holder(s) directly, unless additional rights are indicated by a Creative Commons license in the record and/ or on the work itself. This Thesis has been accepted for inclusion in WVU Graduate Theses, Dissertations, and Problem Reports collection by an authorized administrator of The Research Repository @ WVU. For more information, please contact researchrepository@mail.wvu.edu. 
The Crucible of Globalization:

Latin America in the General Agreement on Tariffs and Trade 1973-1994

\title{
Madison Sergent
}

Thesis submitted

to the Eberly College of Arts and Science

at West Virginia University

in partial fulfillment of the requirements for the degree of

Master of Arts in

History

\author{
James Siekmeier, Ph.D., Chair \\ Mark Tauger, Ph.D. \\ Jack Hammersmith, Ph.D. \\ Department of History
}

Morgantown, West Virginia

2016

Keywords: trade, tariffs, GATT, WTO, Latin America, history, globalization, Tokyo Round, Uruguay Round, economic history, development, trade policy, international organizations, UNCTAD

Copyright 2016 Madison Sergent 


\section{ABSTRACT \\ The Crucible of Globalization: Latin America in the General Agreement on Tariffs and Trade 1973-1994}

\section{Madison Sergent}

Latin America has traditionally not been considered the center of global trade and economic policy, but this common perception is an inadequate view of Latin American foreign policy. Through the use of membership in intergovernmental organizations, specifically the GATT and WTO, Latin American governments were able to advance a development agenda through GATT and later the WTO. While there is a lot of literature on both of these organizations, not much of it has paid attention to the contributions of Latin American member states. Latin American governments cooperated with other developing nations and helped change the international system of trade law to aid in Latin American economic development. 


\section{Table of Contents}

Title i

Abstract ii

Table of Contents iii

$\begin{array}{lr}\text { Introduction and Brief Historiography } & 1\end{array}$

Chapter 1: The Tokyo Round and the Enabling Clause 13

Chapter 2: The GATT Uruguay Round: A Latin American Coup 29

Chapter 3: Ratifying a Latin WTO Document 47

$\begin{array}{ll}\text { Conclusion } & 53\end{array}$ 


\section{Introduction}

It is misunderstanding of the General Agreement on Tariffs and Trade (GATT) (1947) and the World Trade Organization (WTO) (1994) to assume that all decision making power falls into the hands of the United States and its close allies. Since the establishment of the GATT in 1947, several Latin American nations have been its members and Latin American diplomats have had a measurable influence on its development by negotiating preferential treatment in trade deals and ultimately the creation of the WTO during the tumultuous Uruguay Round of negotiations (19861994). What this study seeks to reveal is how Latin American nations achieved these foreign policy goals, what they were able to accomplish in GATT and how did they change the WTO? My argument is that the Latin American nations managed to achieve their goals of preferential trade arrangements through their thorough understanding of the GATT process, building coalitions with other developing nations, as well as their organizational and lobbying efforts in the Tokyo and Uruguay Rounds of GATT and the talks that set up the WTO.

This thesis will examine closely the process by which Latin America pursued a trade reform agenda to promote development through preferential trade agreements within GATT, from the Tokyo Round to the creation of the WTO, and how this process was affected by other GATT members during a period of time that saw great changes in the world economy. Previous interpretations of GATT have not adequately discussed Latin America's influence in GATT and the WTO, so my thesis's ultimate goal is to offer a more complete perspective on how Latin 
America has contributed to the world economic landscape.

It is historically important to appreciate the role of Latin American nations in the creation of the WTO in 1994, after several years of internal debates within GATT. Latin American nations were inevitably involved in relations with more developed nations that sought to control the terms of international trade. Universally, this often-arrogant behavior has earned the ire of Latin nations, who sought to become independent from foreign influences on trade policy, influences such as structural adjustment and the trade goals of other GATT members, but this desire for economic independence was complicated by the degrees to which the nations were involved with the world trade system. These degrees of separation made for an internally complex political and economic system, even though the economic concerns of the Latin GATT members were very similar. In particular Latin American nations are united by the Latin American and Caribbean Economic System, which is an international trade organization that lobbies for Latin trade and development, but this unity was tenuous, for example Mexico's joining NAFTA was considered a betrayal by some Latin ministers during the Uruguay Round.

GATT is of central importance to this analysis for many reasons. Compared to other Bretton Woods organizations, which are focused primarily on lending and spreading US economic policies, the GATT has an almost forum-like quality that I have not seen elsewhere in the literature on development. This is why I consider the GATT to be a place where Latin American diplomats struggle against the competing economic goals of developed nations and why I conceive this place of struggle as a Latin crucible for their development policy.

Of the many regions that were members of the GATT, Latin America was a well represented region. Large nations including Brazil, Argentina, Peru, Mexico and Chile as well as 
smaller nations, including Cuba, and others were contracting parties under GATT. ${ }^{1}$ While all of these nations had individual economic concerns, they shared long-term goals for development and an equal status to the developed nations in world trade. Most historical narratives tend towards a broader picture of the GATT where, instead of narrowing down the contributions of a region or just a few countries, developing nations are treated as a homogenous Third World. This is accurate to the extent that these nations all shared a common goal for improving their countries, but it ignores the variations between nations. What is good for Mexico is not necessarily good for India, and vice-versa. Here, the role of Latin American nations will be examined, because their contributions to the GATT have been understated in the literature.

In the early years between the failure of the International Trade Organization and adoption of the GATT, outside observers began to consider Latin America as a cohesive power bloc in forthcoming trade negotiations. Clair Wilcox, Chairman of the International Trade Conference and Economics Professor at Swarthmore College wrote in 1949 that, "Wealth and income, they [Latin diplomats] argued, should be redistributed between the richer and the poor states. Upon the rich, obligations should be imposed; upon the poor, privileges should be conferred. The former should recognize it as their duty to export capital for the development of backward areas." ${ }^{2}$ These demands were not new within the international system, indeed, since the Bretton Woods Conference they were a central issue. International politics had gained a cooperative spirit outside of the Iron Curtain with the end of World War II and the emerging United Nations was looking like to succeed where the League of Nations had failed. Nothing came from these

\footnotetext{
1 "The 128 Countries That Had Signed GATT by 1994." WTO | GATT Members. 2015. Accessed October 16, 2015. https://www.wto.org/english/thewto e/gattmem_e.htm Many Latin American nations were founding members of the GATT and the roster of Latin American nations in GATT would expand over time. By 1994, Latin America and the Caribbean would have 25 members in GATT.

2 Clair Wilcox. A Charter for World Trade. New York, NY: Macmillan, 1949, 32
} 
early grievances because the International Trade Organization, a sister organization to the World Bank and International Monetary Fund, failed to gain traction in the developed nations. With no strong ITO to regulate trade, progress had long been frustrated by perceived inaction within GATT to address issues such as underdevelopment and certain key industries like agriculture that remained unregulated by international law. To correct this perceived unfairness in trade and to promote development, Latin nations began to pursue aggressive reforms within the GATT to grant developing countries "differential and more favorable treatment," control over mostfavored nation policies, immunities from some tariff reductions, support for Latin economic development plans, more democratic conflict resolution and expanded regulatory powers that would ultimately lead to the creation of the World Trade Organization. ${ }^{3}$ It is these actions which underscore the impact of Latin American nations and form the basis of this thesis.

\section{A Brief GATT Historiography}

The historiography of the GATT and other Bretton Woods organizations embraced a wide variety of historic scholarly writings and many different approaches. This diversity of ideas on the macroeconomic issues of international trade has lead to considerable amount of disagreement among scholars along roughly political lines. The oldest position is that of the Free-Traders, who gained political prominence during the Great Depression. The Free-Traders believe that the liberalization of international trade was a net good for all, reducing costs and encouraging

3 T.N. Srinivasan. Developing Countries and the Multilateral Trading System: From GATT to the Uruguay Round and the Future. Boulder: Westview Press, 1998, 21 
competition within fair, capitalist system. Later, another group, the Protectionists, rose to prominence in both the First and Third World. Protectionists maintain that unlimited economic liberalism is harmful to society because competition is not always fair and that free-trade encourages the dependence of less-developed nations on the goods of developed nations, thus maintaining a hegemonic power relationship. This conflict of economic policy is the backbone of scholarly discussion of most international financial organizations, and it heavily influences the literature.

A classic work on international finance is Sterling-Dollar Diplomacy by Richard N. Gardner (1956), US Ambassador to both Italy and Spain. Garder argues that the post-WWII economic system represented by the various Bretton Woods organizations was a joint US-UK effort to stabilize the world economy. This perspective focuses entirely on wealthy, northern states to understand how the Bretton Woods organizations were created while downplaying the importance of developing nations.

A rival vision of how the world economy truly functioned was envisioned by the Argentinian Central Bank Head and Statistics Minister Raul Prebisch. Prebisch authored such pieces as; "Estructura socioeconómica y crisis del sistema" and "Las teorías neoclásicas del liberalismo económico" in which Prebisch created an alternate, Latin interpretation of the economy and development. ${ }^{4}$ He argued that Free-Trade did not help Latin American nations develop because there were structural barriers within the economy that prevented growth. Prebisch argued that because prices were lower for Latin goods, most of which were exports of crops and raw materials, that Latin America's continued export of materials reinforced the manufacturing power of developed nations. In return, the developed nations would return the raw

4 Raul Prebisch. "Hace una teoria de la transformacion." Revista de la CEPAL, December 2008, 27-71 
materials in the form of manufactured, value added goods. This trade acted as a siphon that shifted capital out of Latin America and into the developed economies. Prebisch's work was later combined with the work of British and UN economist Hans Singer to create the Prebisch-Singer Thesis, which was one of the first dependency theories in economics.

The solution to this system of dependency was to begin using import-substitution industrialization, a topic that is discussed in length later on. Prebisch's continued activism for industrialization and regional unity would lead to him being named the first Director-General of the United Nations Conference on Trade and Development, where he aided in the design of much of the Tokyo Round of GATT's legal reforms, including the Enabling Clause. ${ }^{5}$

While the above work dealt with Bretton Woods in general, there is a large body of writing on GATT itself. The Bretton Woods-GATT System: Retrospect and Prospect After Fifty Years was published by the Institute for Agriculture and Trade Policy, a non-governmental organization interested in promoting the economic success of farmers internationally. This 1996 publication argues that the GATT system has failed to address structural flaws in the world economy and that growing inequality between nations is a major security issue. Specifically, the Bretton Woods organizations were created for the express reason of preventing a global depression in the wake of WWII. The GATT was able to accomplish this goal, but at the cost of ignoring other growing issues like the loss of governmental sovereignty over domestic economies, the rise of multinational corporations, environmental degradation, rising income inequality and the globalization of currency which creates instability. ${ }^{6}$

This failure to address these issues has had a negative impact on all governments,

5 "Misunderstood Moderate; Raul Prebisch." The Economist, March 7, 2009, 78.

6 Orin Kirshner, ed. The Bretton Woods-GATT System: Retrospect and Prospect After Fifty Years. Armonk, New York: M. E. Sharpe, 1996, ix-xi 
including the U.S. Contributor Tran Van-Thinh explains that, "The American economy, for instance, suffers from profound disequilibria: insufficient savings, chronic public deficits, indebtedness of households, businesses, and governments and current-account external deficits. In any other country, such deficits would have led to sanctions by the markets and above all by the International Monetary Fund (IMF)." ${ }^{, 7}$ The solution to these issues is to take on inequality in the market through a social lens by including policies that promote development in the global south, by the people of developing nations while also reinforcing environmental concerns. ${ }^{8}$

The Bretton Woods-GATT System should be considered as both a historic account and an advocacy piece. Unlike most of the other works in the field, it emphasizes the actions of developed nations, especially the U.S. This perspective is unavoidable, given the U.S.'s comparative advantage over international agriculture.

T.N. Srinivasan's Developing Nations and the Multilateral Trading System is a more qualified approval of the GATT framework that builds on the importance of developing nations. The GATT has lived up to its stated goal of reducing tariffs, which it has done every round, but what is more important are the power relationships between developed and developing nations within the GATT. Originally, Srinivasan claims, there was a consensus based decision making process within the GATT that heavily favored the U.S. and its close allies, when the GATT charter only required a simple majority vote. ${ }^{9}$ In this way, the development of the GATT is a tale of structural reform that favors Latin American and other developing nations.

Most reform took place during the Uruguay Round of the GATT negotiations which led to

$7 \quad$ Ibid, 285

8 Ibid, 288, 289

9 T.N. Srinivasan. Developing Countries and the Multilateral Trading System. Boulder, CO: Westview Press, 1998,3 
the creation of the WTO. Developing nations were able to achieve meaningful reforms in the WTO charter, including a ban on the kind of backroom politics that controlled policy in the GATT and by requiring majority votes on decisions. This process favors developing nations because they outnumber and can outvote developed countries. The WTO also includes the Enabling Clause which gives preferential treatment of developing nations in negotiations. ${ }^{10}$ All of these gains have an overall net positive effect, but Srinivasan advises cautious optimism for the future. While developing nations have made gains under the WTO system, they are spread unevenly. More industrialized developing nations stand to benefit much more than Sub-Saharan Africa, which will likely experience a downturn. The WTO's expanded mandate also includes agriculture which will also have mixed results because not every country is reliant on food imports and intellectual property on items such as plants are very controversial. ${ }^{11}$

Developing Countries and the Multilateral Trading System is the first purely historical account of the GATT and the creation of the WTO. Srinivasan puts the focus squarely onto the actions of developing nations, but he uses the same general language of developing nations over the contributions of individual countries to the negotiations. Careful reading makes it is possible to get specific information about individual nations from this work. The main criticism of this volume is its heavy reliance on secondary literature.

Whose Trade Organization by the U.S.-based lobbyist group Public Citizen also opposes further U.S. membership in the World Trade Organization. Where The Bretton Woods-GATT System was concerned with international development, this work focuses entirely on U.S. issues. Lori Wallach and Patrick Woodall argue that the WTO transformed the nature of trade

10 Ibid, 99

11 Srinivasan. Developing Countries. Boulder, CO: Westview Press, 1998, 101 
agreements from enforcing trade rules between different governments to interfering in domestic policy by interfering with food safety standards, product safety rules, investment policy, intellectual property and more in the service of ending the diversity of world governments and creating a globally uniform market for the benefit of multinational companies. ${ }^{12}$ Thus, the WTO is anti-sovereignty and membership within it is counter-productive to U.S. interests.

An example that this study cites of is international law having a combined, deleterious effect on U.S. domestic affairs are the North American Free Trade Agreement and the WTO. By opening up the borders to foreign labor, increased competition between workers has created a race to the bottom where well paid U.S. workers must compete with the below-subsistence wages of Mexican maquiladoras while the profitability of multinational corporations rises. ${ }^{13}$ In their view the solution to WTO interference with global sovereignty is to embrace certain principles in government, including accountability, local regulation, sustainability, cultural diversity and human rights. Specifically this means removing the WTO's ability to make rules on the necessities of life, like access to water and food. The WTO should also be forbidden from interfering with the moral codes of countries who do not believe that objects like plants should be patented. Intellectual property itself should not be enforced internationally, as this leads to ridiculous, legal monopolies. ${ }^{14}$ While there is much need for reform, it is still possible to salvage the WTO into becoming an accountable organization. Whose Trade Organization (2004)would be accurately described as a critical response to earlier works. It is vehemently opposes the WTO for its ability to enforce trade decisions, arguing that it would harm U.S. domestic interests. Like The Bretton Woods-GATT System before it, it is more concerned with U.S. interests.

12 Lori Wallach, and Patrick Woodall. Whose Trade Organization? New York, New York: New Press, 2004,1

13 Wallach, and Woodall. Whose Trade Organization? New York, New York: New Press, 2004, 284

14 Wallach, and Woodall. Whose Trade Organization? New York, New York: New Press, 2004, 287-290 
Fair Trade for All: How Free Trade can Promote Development (2005)by Joseph Stiglitz is similar to Srinivasan's work. Stiglitz, former Senior Vice-President of the World Bank for Development, states that tariff reduction and the removal of trade barriers is good economic policy, but the WTO is perilously close to treating it as ideology, rather than economic policy. Trade liberalization must be carefully controlled for the sake of promoting development of poorer nations, not simply following the Washington Consensus. ${ }^{15}$

Stiglitz maintains that trade liberalization is mostly beneficial to national economies, but some developed nations have behaved in a duplicitous fashion in its pursuit. Developed countries have harmed the interests of developing nations by deregulating strategic industries in developing nations so that the developed nation can undercut their prices. ${ }^{16}$ Here the work takes a comparative lens for studying how economic development has occurred in two regions, East Asia and Latin America. Japan under the Meiji Era (1868-1912) was introduced to the world economy through a series of unfair treaties that kept Japanese tariffs low. This stirred popular resentment of foreign influence over economics which the Meiji implemented through the policy of “fukoku-kyohei” (a wealthy nation and a strong army). The Japanese government became increasingly regulatory of its own economy, including restricting foreign capital, but despite neoliberal economic theory the Japanese economy took off in an unprecedented success. ${ }^{17}$ In comparison, Latin America pursued a policy of import-substitution industrialization. This worked for a few decades, but all progress was lost in the debt crash of the 1980s. What made Latin America fail is debatable. The two leading theories are that import-substitution doesn't

15 Joseph Stiglitz. Fair Trade for All: How Trade Can Promote Development. New York, NY: Oxford University Press, 2005, 2

The Washington Consensus can be defined as a U.S. economic agenda closely tied with neoliberalism, that seeks to extend neoliberal policies worldwide. It is a sort of globalist neoliberalism.

16 Stiglitz. Fair Trade for All. New York, NY: Oxford University Press, 2005, 12

17 Ibid, 15,16 
promote growth, but the more realistic argument is that Latin financial markets were too open. This open investment backfired during the global recession of the 1980s when their debt payments reached almost a third of gross domestic product ${ }^{18}$ Mexico, in particular, is a good example of neoliberalism gone awry, as NAFTA failed to produce long-term growth and at the time of publication in 2005 Mexico had experienced a net loss of jobs. ${ }^{19}$

Fair Trade for All built on the work of Srinivasan to produce a more specific and useful text for understanding methods of development and their relation to world trade. Stiglitz's writing style tended to be more descriptive than other authors within the historiography, including handling economic concepts in a more transparent manner.

As the new left rose to political prominence in academia in the second half of the $20^{\text {th }}$ century, scholars began to focus on the impact of the Bretton Woods system on the Third World, as well as the developing world's influence in world affairs Eric Helleiner, University of Waterloo, wrote Forgotten Foundations of Bretton Woods: International Development and the Making of the Postwar World which argues that Latin America experienced a financial renaissance with the cooperation of sympathetic American economists and that Latin America had influence over the Bretton Woods Conference, including Mexico's chairing of one of the commissions. Helleiner also discusses pre-WWII US economic assistance to Latin America created an ideological basis for future Latin American development programs.

Of particular significance is the narrative of Robert Triffin, who as a part of the Good Neighbor Policy, traveled Latin America as an economic adviser. ${ }^{20}$ In this sense, there is a

18 Ibid, 21, 22

19 Stiglitz. Fair Trade for All. New York, NY: Oxford University Press, 2005, 23

20 Eric Helleiner. Forgotten Foundations of Bretton Woods: International Development and the Making of the Postwar Order. New York: Cornell University Press, 2014. 
similarity between Helleiner's work and this thesis' discussion of GATT Director-General Arthur Dunkel. Both Triffin and Dunkel were both economists from developed nations who worked alongside Latin American economists to promote Latin interests. Triffin helped set up central banks and Arthur Dunkel was instrumental to the successes of the Uruguay Round of GATT.

In a sense, this thesis takes Helleiner's work on the IMF and World Bank and expands it to discuss the GATT. Helleiner made a major contribution to the historiography of Bretton Woods by showing the role that Latin American governments played, which had been overlooked by most of the literature. This work has a similar outlook on the role of Latin American nations in GATT, because GATT is not covered in the historiography of development in the same volume as other organizations and here too does Latin America occupy an important, if understated role. This thesis will demonstrate the historic turn that happened within GATT because of the successful reform movement of GATT that was led by Latin American countries in order to promote their economic development.

What much of this literature focuses on is how the GATT impacts both the developed and developing nations of the world, to the exclusion of Latin American contributions. This work seeks to shift perspective away from the Sterling-Dollar framework of old and demonstrate how truly multilateral the GATT and later the WTO has become. Like Helleiner, this work will expand our collective understanding of the role that Latin American diplomats played in another important international organization. 


\section{Chapter 1:}

\section{The Tokyo Round and the Enabling Clause}

From the creation of the GATT to the beginning of the Tokyo Round in 1973, GATT was concerned almost entirely with tariff issues. Tariffs were seen as economically important to regulate and reduce because they made international trade more costly, as imports were taxed to varying degrees by world governments. Tariff reduction was also seen as a means to prevent financial catastrophes like the Great Depression of the 1930s, but these reductions did not bring growth to Latin America. At first Latin countries were largely indifferent to the tariff negotiations under GATT because they did not stand to gain anything by bargaining; this created a sense of futility among Latin diplomats. ${ }^{21}$ In regards to this deficiency in the GATT Brazil, Chile, Cuba, Peru and Uruguay along with other developing countries issued an internal GATT document to GATT to state their grievances, "The less-developed countries have a number of special difficulties in international trade. Most of these countries are still exporters of primary products, the prices of which are subject to wide fluctuations.",22

These opinions coincided with the earlier Haberler Report from 1958, which was named after the chairman of the commission Gottfried Haberler, Professor of Economics at Harvard. The Latin nations and India had commissioned the report to investigate the tenuous export-based

21 Tandon, Yash, ed. Paved with Good Intentions: Background to the GATT, Uruguay Round and WTO. Harare: Seatini, 2004, 35-36

22 Expansion of International Trade: Note Submitted by the Less-developed Countries. Geneva: GATT, 1959 Accessed October 16, 2015. https://gatt.stanford.edu/page/home, 1 
economies of the developing nations. The report found that prices of primary goods, the main exports of Latin nations, fluctuated wildly, a trend that imposed the vast majority of the economic consequences on developing nations. Prices on Latin exports continued to drop, but the cost for manufactured goods remained the same or increased. ${ }^{23}$ Latin American governments could no longer sustain their WWII-era budgets that were based on reliable prices based on high wartime demand. Such a trend would obviously be ruinous to any state, let alone a state dependent on the export of raw materials. This structural inequity of world capitalist exchange proved the foundation upon which the case for the preferential treatment of developing nations would be built.

From the perspective of Latin governments, the logical solution to this problem was to industrialize, changing the economies from exporters of raw goods and importers of manufactured goods to the reverse. In short, they would be developed industrial economies. This process is called import-substitution development (ISI), and it involves raising tariffs in order to protect nascent national industries from the competition of foreign corporations, thus promoting industrialization and diversification of their economies.

The use of ISI was important to Latin American nations because of how the structure of the world economy works. According to economists like Prebisch and others, Latin America's economy was based on the export of raw materials such as metals, food and other unprocessed materials. Developed countries would buy these raw materials to use in their own manufacturing industries and then resell the finished products back to Latin America. This made Latin America

23 Trends and Developments in International Commodity Trade: Report by the Contracting Parties' Nominee as Chairman of the Interim Co-ordinating Committee for International Commodity Arrangements (ICCICA) to the Contracting Parties to the General Agreement on. Geneva, 1958. Accessed October 16, 2015. https://gatt.stanford.edu/page/home, 2 
dependent on the manufacturing capabilities of other countries and it encouraged dependency on other nations. In addition to the factor of dependency, this system also caused capital to flow out of the developing country and into the coffers of the manufacturers. The only way to end this system was to erect tariff barriers to certain manufactured products until domestic industries could be created in order to compete. Prebisch and others argued that by using ISI, Latin America could develop beyond an extraction economy.

ISI, however, created problems on its own for the Latin GATT members, running counter to the stated goals of GATT, which is to reduce tariffs. These reductions were also reciprocal, meaning all GATT countries must abide by the tariff mandates. Reciprocity was key to the very function of the GATT, because allowing tariffs to be lowered at different rates created issues akin to a free-rider problem in world trade.

While Latin American nations were pursuing ISI, their governments were far more liberal in other areas of commence, like investment, which was not under the jurisdiction of the GATT at first. This allowed relatively open investment behind the tariff walls that these governments erected, but this created its own kind of problems in producing the government structures that would eventually lead to the Debt Crisis of the 1980s.

ISI was not a new, revolutionary economic policy when Latin American nations resolved to begin using it. The United States was one of the better examples of a nation which pursued this strategy. Originally the US was a small country in a world economy with manufacturing titans like the British Empire. As the US rapidly developed industrially in the late $19^{\text {th }}$ century by using tariffs to protect certain key industries, it was able to nurture its domestic production until it was able to compete internationally. This, however, was not the kind of tariff policy that Latin 
America pursued. Latin nations desired a "white blanket" protectionism, where all industries were protected by tariff walls. This policy of white blanket protectionism required that the governments of a developing nation to shift the costs of local industries onto developed nations via tariffs. If the tariffs did not adequately raise government revenues, then they would meet budget shortfalls. ${ }^{24}$

To circumvent these structural barriers within GATT and to practice import-substitution, the Latin nations advocated a change to the GATT itself to give them limited immunity from the reciprocal nature of tariff reduction. This immunity would allow them to maintain higher tariffs on key imports that competed with local industries. Acting as a bloc of developing nations, Latin diplomats argued during the late 1950 s that, “...if reductions in the internal taxes are to be negotiated on the basis of reciprocity and each concession is required to be matched by one of equal value, the less-developed countries may be able to obtain little or no benefit even from any provision making these charges negotiable under the GATT." 25 This argument was economically compelling to the south, but was also tinged with a sort of post-colonial moralist philosophy that favored extending privileges to poor nations. As such it was widely opposed within the US as unfavorable to their trade with Latin America. After all, the US was an economic juggernaut that had comparative advantage and they would not cede it easily to other nations.

Latin America's development concept combined economics and social progress and was older than the GATT itself. This ideology was not unique to Latin America, but it heavily influenced all Latin governments and informed Latin GATT negotiators. An early example of development morality can be seen in the speeches of President Woodrow Wilson who said:

24 Joseph Stiglitz. Globalization and Its Discontents. New York, NY: W.W. Norton \& Company, 2002, 16, 17 25 Expansion of International Trade: Note Submitted by the Less-developed Countries. Geneva: GATT, 1959, 2 
There is one peculiarity about the history of the Latin American States which I am sure they are keenly aware of. You hear of "concessions" to foreign capitalists in Latin America. You do not hear of concessions to foreign capitalists in the United States. They are not granted concessions. They are invited to make investments ... States that are obliged, because their territory does not lie within the main field of modern enterprise and action, to grant concessions are in the condition, that foreign interests are apt to dominate their domestic affairs, a condition of affairs always dangerous and apt to become intolerable. ${ }^{26}$

Despite Wilson's later interventions in Mexico and elsewhere in Latin America, his words would set a First World precedent for describing the systemic barriers that Latin trade and development faced in the world economy.

Latin governments repeatedly addressed their needs to the U.S, hoping both to increase cooperation between American governments and to gain access to American capital. At the 1960 Organization of the American States meeting, the Committee of 21, chaired by Fidel Castro, met in Bogotá to draft a pan-American investment plan to be funded by the U.S. While much of this agreement was Castro's attempts to legitimize his agrarian reform programs, Section III demonstrated the growing idea of development morality by demanding, "additional public and private financial assistance on the part of capital exporting countries of America, Western Europe, and international lending agencies ..." and "technical assistance by the appropriate international agencies in the preparation and implementation of national and regional Latin American development projects and plans;"27 This agreement would later be approved by the OAS, in October 1960. Of course, these policy objectives would carry over into multiple intergovernmental organizations, the GATT being one of them.

Talk of granting more favorable treatment to developing nations would be suppressed

26 Woodrow Wilson. Address of President Woodrow Wilson Delivered before the Southern Commercial Congress Held at Mobile, Ala, October 27, 1913. Washington D.C.: GPO, 1913.

27 Act of Bogota: Measures for Social Improvement and Economic Development Within the Framework of Operation Pan America. Washington, D.C.: Pan American Union, 1961. 
until the Kennedy Round of GATT (1962-1967), which was a US-European Economic Community-dominated trade round that was focused on both tariffs and anti-dumping rules. In 1963 developing nations were once again able to draw political attention back to development. ${ }^{28}$ In the first meeting of the Kennedy Round, the GATT accepted a committee report from the Trade Expansion Programme which included several of the demands of the Latin bloc: first, a standstill provision that would block the erection of new tariff and non-tariff barriers, which would expand GATT power beyond tariff concerns, second, complete immunity from tariffs being placed on all Latin exports by developed nations, with reductions on internal non-tariff barriers including domestic taxes and third the amendment of GATT itself to include official language promoting development. ${ }^{29}$

By the end of the Tokyo Round, Latin American governments had successfully lobbied for the addition of Part IV Trade and Development to GATT. Within Article XXXVI, contracting parties assumed that affording developing nations special privilege would encourage their development and that developed nations had a burden to support this development. ${ }^{30}$ Arguably while impressive on paper, this article on development was only a first step toward addressing Latin grievances. While it did interject the language of development and dependency theory into the GATT, it did not include any specific commitments. Politically, however, this gave Latin America a foothold in GATT for further reform. The only other place that Latin America would be able to make any progress would be outside of GATT, at the United Nations Conference on Trade and Development (UNCTAD) in 1964 and 1968, but there occasions failed to produce

28 Ibid, 24

29 Agenda Item 1. Measures for the Expansion of Trade of Developing Countries as a Means of Furthering Their Economic Development. Geneva: GATT, 1963, 1-2, 11

30 General Agreement on Tariffs and Trade. Geneva, 1986, 53 
demonstrable results. ${ }^{31}$

The Tokyo Round in 1970 was the first instance of a significant bloc of Latin nations allying with other developing countries to form a unified agenda going into GATT negotiations. By that time the GATT had ballooned into a ninety-nine member ministerial conference with developing nations greatly outnumbering developed nations. ${ }^{32}$ This increase in representation was a direct consequence of the spreading force of decolonization. As countries that were formerly controlled by European empires gradually gained independence their former colonial powers often sponsored them for GATT membership under Article XXVI of GATT. ${ }^{33}$ Former colonial powers initiated decolonized states into GATT to assure that the old colonial powers would continue to have access to the resources of their former holdings, and it is highly unlikely that they anticipated such a backlash.

Within Latin America itself different regions began to form multilateral agreements outside of GATT to promote their own exports. In January 1970, Central America, including Guatemala, El Salvador, Honduras, Nicaragua and Costa Rica, formed its own multilateral trade organization, the Central American Common Market, to promote development and increase trade between theemselves. ${ }^{34}$ Over the same period of time, the Latin American Free Trade Association would expand its membership to include Bolivia, Colombia, Ecuador and Venezuela. The Peruvian ambassador assessed the then-current economic outlook, “. . . Latin America annually loses through invisibles more than it receives in the form of aid for development, and this fact, combined with the difficulties of a rugged territory, makes clear the importance of maritime

31 Srinivasan, T.N. Developing Countries and the Multilateral Trading System. Boulder: Westview Press, 1998, 25 32 "The 128 Countries That Had Signed GATT by 1994." WTO | GATT Members. 2015.

33 General Agreement on Tariffs and Trade. Geneva, 1986, 45

34 Central American Common Market. Geneva: GATT, 1970, 2 
transport, with all its consequences in the form of clashes of interest both at the regional level and at the international level." 35

Another trade organization would appear in 1975 to further Latin American economic unity, the Latin American Economic System (SELA, Spanish). The founding constitution for SELA was signed in Panama and contained more specific development language than GATT itself. ${ }^{36}$ SELA, along with other organizations went into the Tokyo Round on good footing by promoting the regional integration of Latin America. All of the regional economic organizations were thus already used to cooperation in economic negotiations and Latin America had a unified development platform to bring into GATT.

The Tokyo Round officially began on September 12, 1973, with the Tokyo Declaration, but as mentioned earlier, Latin American governments were formulating their policies for the Round well before the "official declaration" of a ministerial conference. The stated goals of the Tokyo Round exceeded simple tariff reduction, but also mentioned global poverty reduction and included a clause for securing, ". . . additional benefits for the international trade of developing countries so as to achieve a substantial increase in their foreign exchange earnings, the diversification of exports, the acceleration of the rate of growth of their trade, taking into account their development needs . .."37 This development goal was framed in the same way as was GATT's objective of trade liberalization, suggesting that it was however a top priority of the Tokyo Round. Where Part IV of GATT failed to mention specifics, the Tokyo Declaration did so in Section 2 of the Declaration. It called specifically for the reduction or elimination of non-tariff

35 Customs Unions and Free-Trade Areas - Latin American Free Trade Association: Statement by the Representative of Peru at the Council Meeting of 12 February 1970. Geneva: GATT, 1970, 2-3

36 Convenio De Panama Constitutivo Del Sistema Economico Latinoamericano (SELA). Caracas: SELA, 1975, 5

37 General Agreement of Tariffs and Trade: Tokyo Declaration on Multilateral Trade Negotiations Ministerial Meeting Tokyo, 12-14 September 1973 Declaration. Geneva: GATT, 1973, 1 
barriers, the addition of agriculture to GATT and classified tropical products as a priority sector for deregulation. On paper, this was almost everything that Latin American diplomats could have expected at the start of the round proper. Still, the Declaration was merely a statement of intent and it had no legal power itself.

Recognizing that the Tokyo Declaration was a paper tiger, Latin diplomats continued to lobby for a preferential treatment clause to be included in negotiations, with the ultimate goal of amending GATT. Recalling their earlier success at UNCTAD where the coalition of developing nations was able to secure a unanimous vote in favor of preferential treatment in Resolution 82 , the Latin nations demanded that, "the negotiations shall provide the developing countries with additional benefits that represent a substantial and meaningful improvement of their position in international trade so that they secure an increasing share in the growth in international trade commensurate with the needs of their economic development. ${ }^{38}{ }^{39}$ " When the United Nations could not guarantee progress at UNCTAD, Latin diplomats would take their grievances to GATT, where results might be better.

Agricultural issues were at the forefront of Tokyo Round negotiations for Latin America. Agricultural exports made up around 8-9 percent of total exports from 1970-1995. While this was not an overwhelming percentage of exports, the role of agriculture was still seen as central to the economy of Latin American states because agriculture employed an average 43 percent of the population. ${ }^{40}$ Many of these agricultural exports were specialized in the efficient farming of a single, regional crop in order to maintain a comparative advantage, but at the same time, this led

38 The UNCTAD resolution unanimously decided to aid developing nations with technical assistance to promote GSP systems in the Tokyo Round after the perceived failure of the Kennedy Round.

39 Participation of the Developing Countries in the Multilateral Trade Negotiations. Geneva: GATT, 1974, 1

40 Max Spoor. Two Decades of Adjustment and Agricultural Development in Latin America and the Caribbean. Economic Commission on Latin America and the Caribbean, LC/L. 1352, 2000. 10 
to monoculture exports. Monoculture is inherently risky to trade, because it makes a country dependent on a single crop. The primary trade barriers to tropical product exports were not tariffs, but non-tariff barriers. ${ }^{41}$ The US was probably the worst offender in regard to agricultural barriers, given it its massive subsidization regime for agricultural exports. The artificially cheap US exports undercut the exports of other nations. ${ }^{42}$ The farm subsidy originated as part of the New Deal and it was an American aid program for US farmers. Members of the GATT, who dealt with agricultural products, lobbied extensively to have these subsidies labeled as an unfair trade barrier in their negotiations along with Mexico which had not yet joined GATT. ${ }^{43}$

Mexico was an interesting case. Not yet a contracting party to GATT, the Mexican government still sent delegates to discuss trade. It was among the first Latin nations to begin to codify the "more favorable treatment" rhetoric that would occupy the second half of the Tokyo Round. Mexican diplomats cooperated closely with Brazil and India to tackle quantitative restrictions of world trade and argued for the GATT to adopt a program of automatic restrictions on non-tariff barriers in the favor of developing nations. ${ }^{44}$ Brazil would further codify these principles by proposing the establishment of a new regulatory agency within GATT's Trade Negotiating Committee to arbitrate quantitative barrier issues, hopefully in favor of Latin America. This new agency would, "reach agreement on new and improved rules for the GATT with the objective, inter alia, of consolidating, where appropriate and feasible, differentiated and more favourable provisions designed to improve trade between developed and developing

41 Tropical products include such daily necessities as coffee, in addition to resources like rubber and other goods. 42 Orin Kirshner, ed. The Bretton Woods-GATT System: Retrospect and Prospect After Fifty Years. Armonk, New York: M. E. Sharpe, 1996, 162

43 Multilateral Trade Negotiations Groups "Tropical Products" Points Made by Delegations with Respect to Negotiations on Tropical Products. Geneva: GATT, 1975, 2

44 Proposal by Mexico for Formulating a Special Negotiating Procedure in Accordance with Paragraph 10 of the Tokyo Declaration, for Developing Countries, in Respect of the Elimination of Quantitative Restrictions. Geneva: GATT, 1975, 2 
countries;" ${ }^{45}$ This policy would not be implemented within the Tokyo Round, but in the future Uruguay Round Latin America would succeed in implementing this new agency into the GATT.

The benefits package that developing nations eventually crafted for themselves became widely known as the "Enabling Clause" because it embraced and extended Latin development strategies. ${ }^{46}$ Legally, it granted Latin nations certain immunities from the reciprocal nature of trade negotiations, Latin governments could now reduce their tariffs at a slower rate than other GATT members. Primarily, it granted immunity from the most-favored-nation clause, which meant that Latin nations no longer had to extend the same benefits to all GATT members, allowing them to pick and choose which countries their trade favored. This important exemption from GATT strictures was known as the general system of preferences (GSP), and it gave a great deal of autonomy to developing nations to set tariffs. ${ }^{47}$

The idea of the GSP can be traced back to the work of Latin America diplomats in UNCTAD during the mid-1970s, as the GATT paid close attention to other intergovernmental organizations and had some functional overlap with the Committee on Trade and Development. Within UNCTAD, developed nations were held responsible for assisting developing nations to develop their GSP programs, eliminating all duties on the exports of developing nations and removing all non-tariff barriers to trade. The GSP in UNCTAD was virtually identical to what ultimately was developed in GATT, but the UN Committee was less politically difficult ground for a multitude of reasons. Foremost among these reasons was that the UN Resolution lacks the legal force of GATT, which is a fundamentally legalistic organization built on reciprocal

45 Consultative Group of Eighteen Third Meeting 22-23 June 1976 Memorandum from the Brazilian Delegation on the Improvement of the International Framework for Trade. Geneva: GATT, 1976, 2

46 Here "Enabling Clause" refers specifically to the previsions in GATT Article XVIII Governmental Assistance to Economic Development.

47 T.N. Srinivasan. Developing Countries and the Multilateral Trading System. Boulder: Westview Press, 1998, 24 
agreements. In addition, the tariff reductions brought by GATT membership have a more obvious positive consequence of reducing costs in international trade. ${ }^{48}$

Reactions to the Enabling Clause varied greatly between developed nations at GATT. Japan, for example, had never expected developing nations to be held to the same standards as wealthy countries in the first place, in accordance with the Tokyo Declaration. The official statement of Japan was:

We have already stated and stressed our view that all developed countries should apply the agreed tariff-cutting formula. As far as the developing countries are concerned, we do not expect them to fully associate them selves to the general tariff-cutting formula. The developing countries would thus be in a position to enjoy fully the benefits accruing to them by the MFN tariff reductions on the part of the developed countries ...

Japan's only qualms about the GSP system under the Enabling Clause was that it should be transparent. If tariffs were reported to GATT, then the ministers could issue advice on products case by case. ${ }^{49}$

The European Economic Community was also in favor of granting special privileges to developing nations, including Latin America, but with more restrictions than Japan suggested. The EEC believed that allowing unlimited application of the GSP to all products would be counterproductive. The EEC was willing to compromise on this point by saying that they would reduce their tariffs on certain countries, proportional to their perceived underdevelopment, but in exchange the developing nations would have to offer a substantial, but not equal, tariff reductions. $^{50}$

America was opposed to granting Latin nations the GSP. The US argued that such a power

48 UNCTAD Resolutions on the Generalized System of Preferences. Geneva: GATT, 1975, 3

49 Special and More Favourable Treatment for Developing Countries Statement Made by the Delegation of Japan at the Group "Tariffs" Meeting, December 1976. Geneva: GATT, 1976, 1, 3

50 Special and More Favourable Treatment for Developing Countries Statement Made by the Delegation of the Commission of the European Communities at the Group "Tariffs" Meeting, December 1976. Geneva: GATT, 1976, 1, 6, 7 
would be largely redundant with the normal GATT tariff reductions, which the US would consider modifying for Latin nations on a case-by-case basis. The GSP was seen as a matter outside the scope of the committee, a temporary measure that should not be made permanent. To grant broad GSP powers to developing nations would violate basic GATT principles of tariff reductions. Ultimately the US delegation declared, "As the United States has stated in the past, it can neither agree to binding its GSP rates nor to binding GSP margins of preference." ${ }^{51}$

Domestically, getting the Tokyo Round Agreements through the United States Senate would be another challenge altogether because of how trade agreements are approved within the US. While the executive handles the fine details of negotiations via the Treasury Department, the Senate has ultimate authority to approve agreements. This is usually done through "Fast-Track" legislation that allows the President to negotiate without Congressional oversight and present the final agreements of any GATT round and a final bill, with no latitude for Congress to make amendments. The Senate must either pass it wholesale or block it. ${ }^{52}$ Primarily, Senate members were beginning to worry about the effects of more liberal world trade on domestic unemployment in the US. This, coupled with the oil shocks in the Nixon years, created a US domestic political environment within the US that was hostile to the Tokyo Round Agreements. ${ }^{53}$ Still, the Tokyo Round Agreements Act passed the U.S. Senate almost unanimously 90-4 as the Trade Agreements Act of 1979 on July, 26 1979, despite these domestic concerns. The act itself was evidence of the sheer political might of the Executive Branch, having been fast-tracked through without Congressional oversight. In a nod to the protectionists' grievances, the bill

51 Special and More Favourable Treatment for Developing Countries Statement Made by the United States Delegation at the Group "Tariffs" Meeting, December 1976. Geneva: GATT, 1976, 2, 3

52 C.R. Neu and Emery Simon. U.S. Trade Policy and the Tokyo Round of Multilateral Trade Negotiations. 53 Ibid, 5 Washington D.C.: GPO, 1979, ix 
included Title IX: Enforcement of United States Rights. This section gave the president authority to protect US interests without petition or without consulting Congress. ${ }^{54}$ Protectionists would continue to worry about this growth of executive power as these issues would carry over into the GATT Uruguay Round.

Over the objection of the US, the Enabling Clause was included within the text of GATT at the conclusion of the Tokyo Round, but how much benefit did this seemingly small victory provide? The text of the clause itself was reassuring to Latin nations as it both guaranteed GSP rights and also forbade a developed nation from demanding further concessions that would go against the interests of developing nations or demand, "contributions [tariff reductions from developing countries] which are inconsistent with their individual development, financial and trade needs. ${ }^{" 55}$

While the Enabling Clause was strongly worded, it would not be the hoped-for silver bullet for development that Latin America needed. First, the stipulations on agriculture fell through due to American and European resistance to reducing non-tariff barriers. Agriculture was a constant thorn in the side of Latin trade because Latin nations could not afford the types of subsidies that US farmers received. ${ }^{56}$ Second, the US was in an advantageous economic and political position where it could afford to ignore the GATT's decision entirely and instead require countries to make private bilateral agreements on the GSP before the US would accept their tariffs. This was done outside of the scope of official GATT meetings in the form of private meetings at ministerial conferences where negotiations were not recorded. These agreements

54 Russel B. Long "S.1376 — 96th Congress (1979-1980)." Congress.gov. Accessed March 9, 2016. https://www.congress.gov/bill/96th-congress/senate-bill/1376.

55 Special and More Favourable Treatment Reciprocity and Fuller Participation of Developing Countries Decision of 28 November 1979. Geneva: GATT, 1979, 3

56 Orin Kirshner, ed. The Bretton Woods-GATT System: Retrospect and Prospect After Fifty Years. Armonk, New York: M. E. Sharpe, 1996, 162, 163 
were commonly referred to as "Green Room" negotiations. ${ }^{57}$ The United States would continue to use this power to act unilaterally in negotiations, even though the GATT was designed for multilateral negotiations. Most significantly, however, was the fact that import-substitution development would not succeed in developing Latin America. By protecting too many industries from foreign competition through the use of the GSP, Latin governments kept their economies inefficient. The costs of high tariffs were passed down to consumers, rather than being used to expand domestic industries. This analysis of the effects of the GSP and nationalized industries is somewhat controversial within the secondary literature. Scholars with a background in neoclassical economics generally view nationalized industries as both wastes of government funds and potential breeders of corruption, whereas writers coming from a New Left perspective disagree with this assessment by claiming that nationalizing industry is a part of sovereignty and that private firms should not be trusted with key strategic industries. Monoculture, the government ownership of industries and loose monetary policy were all important factors that comprised an economic nationalist policy of many Latin American nations and these factors completed a recipe for hyperinflation and the debt crash of the $1980 \mathrm{~s}^{58}$

Latin diplomats would continue advocate for their development policies in any intergovernmental organization to during GATT negotiations. The United Nations offered a good place for developing nations to debate development, especially at the United Nations Conference on Trade and Development. The UN General Assembly, having a majority of developing nations as members, drafted a proposal for a New World Economic Order in 1974 that drew heavily on past elements of development morality. In 1974, the General Assembly passed a Declaration on

57 Srinivasan, T.N. Developing Countries and the Multilateral Trading System. Boulder: Westview Press, 1998, 26 58 Stiglitz, Joseph. Globalization and Its Discontents. New York, NY: W.W. Norton \& Company, 2002, 53 
the Establishment of a New International Economic Order [NIEO] which called for:

... the Establishment of a New International Economic Order based on equity, sovereign equality, interdependence, common interest and cooperation among all States, irrespective of their economic and social systems which shall correct inequalities and redress existing injustices, make it possible to eliminate the widening gap between the developed and the developing countries and ensure steadily accelerating economic and social development..." ${ }^{59}$

Outside of GATT, the NIEO concept would serve as the most up to date perspective on development and the role of Latin America in development. Here the economic position of Latin America was framed as an injustice inflicted on Latin Americans by the systemic oppression from the wealthy nations. This original economic sin was based largely on the heritage of colonialism and continuing via neocolonialism, to the detriment of development. The New International Economic Order did offer a solution to this problem, one that was reminiscent of the OAS plan from fourteen years earlier. The developed nations could provide investment capital for developing Latin nations, so that the developing nations could participate as equals in world trade. Agreement among the developing nations was so strong on this issue that cooperation among the governments of the Third World reached the highest point of intergovernmental solidarity. This powerful coalition would be led by countries which include Brazil and India and this cooperation would be the hallmark of the negotiations of the Tokyo Round. ${ }^{60}$

59 Resolution Adopted by the General Assembly 3201 (S-VI). Declaration on the Establishment of a New International Economic Order. New York: United Nations, 1974.

60 Srinivasan, T.N. Developing Countries and the Multilateral Trading System. Boulder: Westview Press, 1998, 25 


\section{Chapter 2:}

\section{The GATT Uruguay Round: A Latin American Coup}

After the conclusion of the Tokyo Round in 1979, there was no pause in the economic negotiations by Latin America. While there were no ministerial meetings, nations prepared for the inevitable next round of multilateral negotiations. The five year gap from the end of the Tokyo Round in 1979 to 1984 and the Punta del Este Declaration would be in anticipation of the most momentous and final round of GATT negotiations.

In this interim period Mexico finally applied for and was granted GATT membership. While Mexico's application was submitted before the end of Tokyo Round negotiations, its application was conditional. The application was predicated on the acceptance of the Enabling Clause by GATT and thus being "governed by the principles in favour of developing countries set forth in the... Ministerial Declaration signed at Tokyo, Japan..." ${ }^{61}$ Had the introduction of the Enabling Clause failed, Mexico would not have joined GATT. As discussed in the previous chapter, the Enabling Clause did pass, but its intent was not always honored.

The context under which the 1986 Uruguay Round occurred would be a departure from the economic conditions of the 1970s and the Tokyo Round. At this time the economic history of the United States was hurt by the OPEC oil crisis and its deleterious effects on the US economy. US citizens experienced crippling gas rationing and a dollar that was plummeting in value. Internationally, this was accompanied by the collapse (in the 1971-1973 period) of one of the 61 Accession of Mexico. Geneva: GATT, 1979. 
cornerstones of the Bretton Woods System, the Gold Standard, which pegged the dollar to gold and all other major currencies to the dollar. While America was experiencing a nightmare of stagnant growth and inflation, commonly described as stagflation, Latin America was also being affected by global financial events, stagflation effected their economies causing disastrous losses of government revenue. This was slightly more tolerable to countries like Venezuela, who possessed large oil reserves which became more valuable during the oil shocks.

The success of Latin nations in gaining GSP rights at the Tokyo Round was checked by a lack of progress in economic development in practice has been referred to as "bicycle theory",62 by some economists. It is generally easier for nations to raise trade barriers unilaterally than for multilateral negotiations to dismantle those barriers. This was evident at the end of the Tokyo Round when the Enabling Clause was effectively nullified by non-tariff barriers such as subsidies in developed nations, particularly the US. ${ }^{63}$ As the US continued to act unilaterally, the financial situation in Latin America worsened. Beginning in August of 1982 the Latin American nations began to experience a debt crisis. A major factor in this crisis was the phenomenon of hot money, which the IMF described as occuring when:

one country or sector in the world economy experiences a financial crisis; capital flows out in a panic; investors seek a more attractive destination for their money. In the next destination, capital inflows create a boom that is accompanied by rising indebtedness, rising asset prices and booming consumption for a time. But all too often, these capital inflows are followed by another crisis. Some commentators describe these patterns of capital flows as hot money that flows from one sector or country to the next and leaves behind a trail of destruction. ${ }^{64}$

Hot money that had flowed into Latin nations left and countries had to engage in deficit spending

62 Bicycle Theory is a metaphor that shows the lack of progress that developing nations experience, no matter how much their countries invest in their economies. In a sense, nations are pedaling-in-place, stuck in economic limbo.

63 Yash Tandon, and Megan Allardice, eds. Paved with Good Intentions: Background to the GATT, Uruguay Round and WTO. Harare: Seatini, 2004, 52

64 Anton Korinek. "Hot Money and Serial Financial Crises.” IMF, 2010, 1 
to continue their social development plans. Oil prices also began to drop, harming many Latin countries whose primary export was oil and reducing the incomes of those countries until they could no longer repay their outstanding debts. Many of the hard-won benefits of Latin nations were lost by the International Monetary Fund (IMF) structural adjustment, punitive budget reforms imposed by international creditors. ${ }^{65}$

The 1980s would be known as the "Lost Decade" to Latin American economists. All of the financial gains brought by the limited victory of the Tokyo Round would evaporate during the 1980s, and by the 1990s Latin American gross domestic product fell below 1970 levels for many. The crisis not only reduced productivity but also reduced the wages of Latin American workers by 20 to 40 percent. The lack of a real wage combined with double-digit inflation led to unemployment and poverty in Latin America that drove workers to migrate into the north from South and Central America. ${ }^{66}$

The loans of hot money, some of which was recycled OPEC petro-dollars, that many Latin American governments had taken to provide for infrastructure and other basic needs, including road building and other improvements, were impossible for Latin American governments to pay back. Faced with the prospect of virtually an entire continent declaring bankruptcy, however, the IMF stepped in to provide loans to bail out the debtor governments. This badly needed capital came with strings attached. Latin American governments would have to submit to a series of "structural adjustments" to their economies, changes guided by the IMF. ${ }^{67}$

Structural adjustment had disastrous effects on Latin American economies. The IMF took

65 Kendall Stiles. "Negotiating Institutional Reform: The Uruguay Round, the GATT, and the WTO." Global Governance 2, no. 1 (1996): 119-48, 126

66 David Felix. "Latin America's Debt Crisis." World Policy Journal 7, no. 4 (1990): 733-71. 733

67 David Felix. "Latin America's Debt Crisis." World Policy Journal 7, no. 4 (1990): 733-71. 739 
much of its ideology from the US Treasury Department and neoliberal policies, the IMF would impose aggressive austerity programs and force Latin American nations to sell off state-owned industries, among other changes. ${ }^{68}$ Internationally, the IMF coerced Latin American governments to lower the carefully made tariff barriers that were created under the GSP. Thus exposed, domestic Latin American industries withered in the face of foreign competition, and many Latin American governments would collapse under the strain. Bolivia would go to great pains to implement structural adjustments, but it would not grow its economy as the IMF promised. Argentina's government eventually collapsed in a popular revolt in 2001 after decades of economic suffering. ${ }^{69}$

Interestingly enough the original impetus for a new round of GATT negotiations came from the US in 1982, rather than a developing nation. Specifically, the US desired to add agreements on services and intellectual property to GATT, but this call met resistance. Brazil, in cooperation with India in the Group of Ten, tried to block the next round until the developed nations agreed to honor their commitments from the previous one. Brazil was also concerned with its ability to meet with the US on equal terms when discussing intellectual property. Brazil would only agree to the new round if the developed nations agreeing to some starting commitments, including a stand-still demand to not create any more non-tariff barriers and for developed nations to remove the barriers that they raised after the end of the Tokyo Round. ${ }^{70}$ Representatives from Uruguay further defined Brazil's position on new negotiations via a position paper in 1984 . This paper asserted that Latin growth had begun to stagnate and claimed

68 Neoliberalism is a political movement that began in the US and UK. It argues from the work of Austrian economist Milton Friedman and the philosophy holds that government should not interfere with the market.

69 Joseph Stiglitz. Globalization and Its Discontents. New York, NY: W.W. Norton \& Company, 2002, 18

70 Srinivasan, T.N. Developing Countries and the Multilateral Trading System. Boulder: Westview Press, 1998, 29 
that the existing economic outlook was grim. The blame for this situation was laid at the feet of developed nations, which had increased barriers to Latin exports by refusing to lower non-tariff barriers combined with the use of structural adjustment to change Latin GSP policies. Uruguay then called for the developed nations to abide by their agreements during the Tokyo Round by removing their tariffs and imposing a freeze on new ones, ending domestic subsidies, liberalizing textile imports and honoring the letter and spirit of the Enabling Clause. The logic behind these demands seemed simple to Uruguay, after all the developed nations had already agreed to do these things during the Tokyo Round. This position required no new meetings, merely enforcement of what had been promised to Latin nations. Until this was done, Uruguay argued, the GATT could not be taken seriously by Latin nations and there would be no point in further dialogue if GATT decisions could be so easily abrogated by the developed countries. ${ }^{71}$

In opposition to Uruguay's position piece Trade Policies for a Better Future: Proposals for Action (1985), a GATT report, also known as the Leutwiler Report, named after Dr. Fritz Leutwiler head of the Swiss Central Bank. This report was not commissioned by a specific nation, but by a request of the GATT Director-General Arthur Dunkel. The report backed the US position, stating that a new round of GATT negotiations was needed, especially to cover services. After this report was published, the Organization for Economic Cooperation and Development (OECD), an intergovernmental organization comprised mostly of developed nations, endorsed the US position in favor of new negotiations. Several Latin nations including Argentina, Brazil, Colombia, Cuba, Nicaragua, Peru and Uruguay remained opposed to the upcoming round, but political pressure was beginning to turn against them.

71 Improvement of World Trade Relations Through the Implementation of the Work Programme of GATT. Geneva: GATT, 1984. 
ASEAN nations had agreed to new negotiations and soon Latin America found itself to be the last holdout on the new round. ASEAN agreed to the round for many reasons, including the relative difference in wealth between ASEAN and Latin American nations. ASEAN contains Singapore, one of Asia's Tiger economies, and in comparison to Latin America the region was experiencing vigorous growth. Faced with no alternative, Latin America agreed to the new negotiations despite their reservations. ${ }^{72}$ This pressure from ASEAN would be one of the first cracks that would lead to the dissolution of the cooperation between Latin America and other regions of developing countries.

The Uruguay Round of GATT began in 1986 with the Punta del Este Declaration. In the goals stated in the Declaration the first interesting point is that the delegates anticipated that the round would only take four years to complete. In contrast to this optimistic outlook, the Uruguay Round dragged on for the better part of a decade and ended with the creation of the World Trade Organization. $^{73}$

Economically speaking, the Punta del Este Declaration had five main goals, including removing trade barriers, lowering tariffs, openness, promoting development and consideration of growing third world debt. ${ }^{74}$ In comparison to the Tokyo Declaration, the Punta del Este Declaration was much broader in scope and more specific in goals. The only two stated goals of the Tokyo Declaration had been the reduction of tariffs and the reforms that created the Enabling Clause, but at Punta del Este the delegates included non-tariff barriers and the growing problem of debt among developing nations. ${ }^{75} \mathrm{New}$ issues included agriculture, intellectual property and

72 Tandon, Yash, and Allardice, Megan, eds. Paved with Good Intentions: Background to the GATT, Uruguay Round and WTO. Harare: Seatini, 2004, 57, 58

73 General Agreement on Tariffs and Trade (GATT) Punta del Este Declaration. Geneva: GATT, 1984, 1

74 Ibid, 1

75 General Agreement of Tariffs and Trade: Tokyo Declaration on Multilateral Trade Negotiations Ministerial Meeting Tokyo, 12-14 September 1973 Declaration. Geneva: GATT, 1973, 1 
investment, all primarily US positions, but while Brazil's Group of Ten ${ }^{76}$ ceded much in the declaration they also gained a section on the stand-still and rollback on the type of anti-GATT measures that the US had been taking at the end of the Tokyo Round, like the US refusal to end agriculture subsidies and other non-tariff barriers. In addition to this, it was finally acknowledged that the GATT's enforcement protocols were too weak to be effective and that major reform was needed to end the tradition of Green Room practices of the major developed nations and to give GATT legal teeth. ${ }^{77}$

The section on decision-making was an important inclusion within the Punta del Este Declaration because GATT's legal language had been so weak. Within GATT, contracting parties were expected to comply with decisions rendered by group negotiations, but the only penalty for disregarding a deal was loss of GATT privileges, including most favored nation status from other GATT members. This constituted a system of liability rules rather than property rules, because an offender could simply pay off a penalty instead of being forced to comply. Obviously, this had more effect on the exports of a developing nation in comparison to its effect on the exports of developed nations. As developed nations have the budget surpluses to ignore GATT decisions, this system would have to be fixed in the Uruguay Round. ${ }^{78}$

After the first meeting in Punta del Este, negotiations accomplish little until the 1988 Montreal Conference. Of the fifteen different groups that were supposed to meet, only six had a text ready for discussion at the meeting. This was a recipe for chaos, one worsened when the US, which was experiencing a growing public awareness of its changing balance of trade. At

76 The Group of Ten was the smallest power bloc within the Uruguay Round. Led primarily by Brazil and India, the group represented most of Latin America.

77 General Agreement on Tariffs and Trade (GATT) Punta del Este Declaration. Geneva: GATT, 1984, 3-5

78 Douglas Irwin, Mavroidis, Petros and Sykes, Alan. The Genesis of the GATT. New York, NY: Cambridge University Press, 2008, 166 
approximately the same time Congress passed the Omnibus Foreign Trade and Competitiveness Act, a unilateral act that required targeted nations to reduce their trade surpluses bilaterally or be subject to increased tariffs. This act specifically named Brazil and India as offenders in the areas of liberalizing investment and intellectual property, most likely in retaliation for the Group of Ten's resistance to the Uruguay Round. ${ }^{79}$ In addition to this US political reprisal, a rift on agricultural issues formed between the US and European Community. As both of these power blocs had an effective veto power, negotiations were brought to a grinding halt. At the same time this rift allowed Brazil and its allies to make progress on tropical products, dispute settlement, tariff reductions and a review system for trade policy. In this sense, while Brazil's Group of Ten bloc did not represent all developing nations, Latin America had reached the zenith of its negotiating power under the GATT system. ${ }^{80}$ There was still resistance to the Latin nations eventual control of half of the committees, but the GATT Secretariat itself was favorable to the Latin cause. While there was US pressure to "graduate" Brazil from its status as a developing nation, the secretariat ruled that this was against the spirit of the Enabling Clause and that the Omnibus Act was a violation of GATT. ${ }^{81}$ The Group of Ten and the GATT Secretariat would add the developing country language in the Enabling Clause into GATT's arbitration rules and add arbitration rules in addition add to surveillance system first proposed back during the Tokyo Round for these decisions into GATT. ${ }^{82}$

Latin American nations had to chose sides carefully on the issues that the US and other

79 Srinivasan, T.N. Developing Countries and the Multilateral Trading System. Boulder: Westview Press, 1998,33 80 Gilbert Winham. "Gatt and the International Trade Regime." International Journal 45, no. 3 (1990): 796-822., 813

81 Differential and More Favourable Treatment of Developing Countries in the GATT Dispute Settlement System Note by the Secretariat Revision. Geneva: GATT, 1988, 6

82 Improvements to the GATT Dispute Settlement Rules and Procedures Decision of 12 April 1989. Geneva: GATT, $1989,3,8$ 
developed nations were debating, lest their attempts to pursue institutional changes be compromised. In a diplomatic sense, Latin American governments largely gave ground on the issues of agriculture, trade-related investments (TRIMs) and intellectual property (TRIPs) in order to focus on the institutional issues.$^{83}$ The issue of TRIMs and TRIPs was very divisive to economists, as they saw the inclusion of TRIMs and TRIPs under GATT would lead to price increases in Latin America, creating a transfer of wealth to patent-holding developed nations, but at the same time it would potentially encourage investors to invest in Latin America without the fear of having proprietary information copied. ${ }^{84}$ The inclusion of both of these issues into GATT forced Latin American governments to change their domestic laws governing investment and intellectual property.

Agriculture was the most difficult of these issues to work with because of the power of the agricultural lobbies in the developed nations. The US and EC would significantly delay the Uruguay Round, arguing this issue. Latin America's perennial demand in this area was the elimination of non-tariff barriers like farm subsidies that both the US and EC used extensively. During the Tokyo Round, the Enabling Clause gave Latin American governments the ability to maintain subsidies for their own staple exports, but they still could not match the volume of US subsidies. Their solution was to encourage "tariffication," the conversion of subsidies into tariffs of the same value. Latin American governments hoped that if these subsidies were converted into tariffs, then it would be possible to negotiate them lower in future negotiations, but it did not work out so simply. Many countries would actually set these new tariffs far in excess of the

83 TRIMs and TRIPs refer to liberalized investment policies in GATT nations and the mutual acceptance of patents from other GATT nations. This could be problematic because investment was partially to blame for the debt crisis and some developing nations had comparatively large patent durations.

84 Srinivasan, T.N. Developing Countries and the Multilateral Trading System. Boulder: Westview Press, 1998, 52 
actual averages (AA) of their subsidies. The US for example would set a beef tariff of 31 percent when the AA was only 3 percent. Thailand, a member of ASEAN and a net exporter of rice, set a tariff of 58 percent on rice. ${ }^{85}$

TRIMs and TRIPs were both new in GATT, issues that were introduced during the Uruguay Round. Some scholars like Joseph Stiglitz have blamed the openness of Latin American financial markets for causing the debt crisis of the $1980 \mathrm{~s} .{ }^{86}$ In this sense TRIMs had already done their damage to Latin America, and it was too late to prevent damage, but the same was not true for TRIPs. TRIPs were another possible path to development, by domestically researching, acquiring or copying intellectual property including technologies, Latin manufacturing could be greatly improved. This knowledge capital was prized by Latin American governments, but major developed nations sought to clamp down on the ability to copy the inventions of multinational corporations. In the short term these reciprocal intellectual property agreements would require Latin American governments to change how their copyright systems and patent systems would work, leading to a short term increase in prices in products like medicines and other complex products. It was thought that the new TRIPs rules in GATT would not greatly damage Latin economies because the changes were designed to be gradual, however there is no quantitative data to back this claim. ${ }^{87}$

Negotiations would resume in 1990 at the Brussels Ministerial Conference, where, temporarily, the European Economic Communities and US reached a compromise on agriculture. At this time Uruguay's representative compiled a report of developments to be shared among other SELA members at Brussels. Overall, Uruguay's analysis of the Uruguay Round was

85 Srinivasan, T.N. Developing Countries and the Multilateral Trading System. Boulder: Westview Press, 1998, 33 86 Stiglitz. Fair Trade for All. New York, NY: Oxford University Press, 2005, 15-16

87 Srinivasan, T.N. Developing Countries and the Multilateral Trading System. Boulder: Westview Press, 1998, 52 
positive. Latin America would receive benefits, including progressive trade liberalization, automatic most-favored-nation status and an increased ability to participate in decisions, but the negotiations on trade-related intellectual property, investment and services were not incorporating the Enabling Clause ${ }^{88}$ Unlike in the case of tariffs, Latin nations were expected to immediately bring their investment and intellectual properties in line with the rest of GATT, without the protections offered by the Enabling Clause.

SELA's cautious but optimistic outlook on the future of GATT was not shared universally by all Latin nations. At Brussels, Cuban Deputy Minister of Foreign Trade Alberto Roa gave a much darker assessment on where the economy was headed:

The question of external indebtedness deserves an entire statement to itself. Between 1982 and 1990 the transfer of financial resources by Latin America for debt servicing reached almost US $\$ 300$ billion, which is tantamount to transferring abroad an average of 4.1 per cent of the GDP annually. The debt burden continues to grow. With its voracious appetite it has already devoured the social programmes of most of our countries and is threatening to swallow up completely what is left of our standards of living, including those of the middle classes, and our possibilities of growth are no longer even a subject of concern, because they simply do not exist. The external debt of the developing countries cannot be repaid; it cannot technically be repaid or technically recovered. What is more, it has already been more than repaid and more than recovered more than once. ${ }^{89}$

When these figures are compared to the projected economic gains of the Uruguay Round, it almost completely annuls the gains of Brazil and many other Latin American nations. This penalty would completely negate all of Mexico's projected financial gains. ${ }^{90}$ These grim statistics lend credence to the claim that the 1980 s were truly a decade of lost progress. ${ }^{91}$

88 Evaluation On The Situation Of The Uruguay Round: Communication from the Permanent Representative of Uruguay on Behalf of SELA. Geneva: GATT, 1990, 30-32

89 Meeting at Ministerial Level Brussels, December 1990 CUBA Statement by H.E. Mr. Alberto Betancourt Roa, Deputy Minister of Foreign Trade. Geneva: GATT, 1990, 2

90 Glenn Harrison, Thomas Rutherford and David G. Tarr. "Quantifying the Uruguay Round." In Will Martin and L. Alan Winters, eds, The Uruguay Round and the Developing Countries. Cambridge: Cambridge University Press, pp. 183-215, Table 8.7

91 Ernesto Talvi. Think Tank 20: Growth, Convergence and Income Distribution: The Road from the Brisbane G20 Summit: Latin America's Decade of Development-less Growth. Washington D.C.: Brookings Institute, 
The GATT ministerial in Brussels eventually failed as the US and EC fell back into arguing over agricultural issues, but a draft of the Uruguay's Round's final act was published. The massive three hundred and ninety-five page document would not be accepted by the GATT parties, and it would look nothing like later drafts. The developing nations rejected this draft because, “. . . they were being asked to undertake heavy obligations in such areas as TRIPs, TRIMs and Services, their needs and interests had been covered only in a partial, unbalanced and hence unsatisfactory way. ${ }^{92}$ " Progress was made on intellectual property, investment and services, but the continuing US-EC feud frustrated all further progress. In a last minute attempt to save the Uruguay Round, the GATT Secretariat decided that it must dramatically reorganize the negotiating committees. The list of fifteen previous committees, many under the control of Latin countries, were reduced to seven. Latin America was able to maintain control of two committees, Brazil being in charge of rule-making and Uruguay, which included the Final Act and dispute settlement groups. ${ }^{93}$ Hoping to spur negotiations, Arthur Dunkel issued a tentative deadline of December 1991 to complete a final draft for the Uruguay Round, but the breakup of the Soviet Union, subsequent requests to GATT by Russia and the failure of the US and EC to resolve their differences at the G-7 Meeting would cause the GATT to miss Dunkel's deadline. In an attempt to address the wide gulf that existed between the developed nations, Dunkel's Secretariat issued a draft of the Final Act of the Uruguay Round, but this document would be no more than a framework that was missing key issues and lacked a consensus behind it. ${ }^{94}$

A certain historic parallel can be observed between the work of Arthur Dunkel and Robert

2013, 36

92 Trade Negotiations Committee: Twenty-first Meeting: 13 January 1992. Geneva: GATT, 1992. 4

93 New Negotiating Structure and Chairmen Agreed in TNC. Geneva: GATT, 1991.

94 Srinivasan, T.N. Developing Countries and the Multilateral Trading System. Boulder: Westview Press, 1998, 33 
Triffin of the US Federal Reserve Board who in 1943 and 1944 led an advisory mission to Paraguay. As part of the Good Neighbor Policy, Triffin was very respectful of his Latin American economist peers and cooperated with them to promote monetary reforms..$^{95}$ Triffin traveled to Latin America, setting up central banks and currencies to aid Latin Americans both in the short term and developmental efforts. Comparatively Arthur Dunkel was surely concerned about his legacy as he viewed a GATT round stagnating, becoming simply a place for the US and ECC to bicker about agriculture. To this end, Dunkel used his powers as Director-General to catalyze the meeting by reorganizing the GATT committees and personally aiding in the Dunkel Draft of the Uruguay Round Agreements. It was this draft that later became the WTO after revision. Both Triffin's and Dunkel's commitment to multilateralism and development combined with their listening to and acting upon the needs expressed by Latin American nations to demonstrate further the ideological dimension of development going into the Uruguay Round.

Mexico issued a detailed statement on this draft Final Act that addressed Mexico's particular grievances with liberalization, grievances relating to Article XXVII of the Mexican constitution which forbids foreign nationals from owning Mexican land or water rights in certain areas and also bans land ownership by non-Mexican citizens. If foreigners broke Mexican law and did not submit to Mexican justice or if the party were found guilty in a trial, the Mexican constitution allows the state to confiscate all of the offender's holdings. ${ }^{96}$ This constitutional provision had a long history within Mexico and under new trade-related investment measures, the Mexican constitution could be declared a non-tariff barrier. ${ }^{97}$

95 Helleiner, Eric. Forgotten Foundations of Bretton Woods: International Development and the Making of the Postwar Order. New York: Cornell University Press, 2014, 139

96 Communication from Mexico Conditional List of Offers of Mexico Revision. Geneva: GATT, 1992,3

97 Ibid, 5-6 
The deadlock on the Uruguay Round would continue until November 1992. Time was beginning to press down on the US President, whose fast-track privileges were set to expire the following June. Incoming President Bill Clinton, who took office in January 1993, was able to secure an extension from Congress. In the meantime Clinton attended a meeting of the AsiaPacific Economic Cooperation (APEC) forum in Seattle, Washington. At this APEC meeting the Asian nations who were also represented in the Group of Forty offered additional tariff concessions on agriculture beyond those previously agreed to in the last Uruguay Round Draft. The Group of Forty, combined with the political weight of the US, added together to comprise forty percent of the global economy. Sensing defeat if it could not compromise with the US, the EC saw the writing on the wall and became less recalcitrant in negotiations. ${ }^{98}$

From the Latin standpoint, it was important to end the US-EC deadlock as soon as possible in order to prepare a Final Act for acceptance. The Cairns Group, an export association of agricultural countries including Argentina, Brazil, Chile, Colombia and Uruguay, released a statement in July 1993, highlighting the importance of breaking the deadlock. ${ }^{99}$ The Cairns Group listed the essential policy steps to reform agriculture as reductions of domestic subsidies, export subsidies and other non-tariff barriers. This agreement would ultimately be reached between the US and EC in the Blair House Accord, which allowed negotiations to move past agricultural issues towards creating a final draft document. The Blair House Accord was a bilateral agreement in keeping with the US's unilateral behavior through GATT to mutually lower domestic and export subsidies along with the EEC. The final draft of the Uruguay Round

98 Srinivasan, T.N. Developing Countries and the Multilateral Trading System. Boulder: Westview Press, 1998, 34

99 The Cairns Group is a coalition of 19 agricultural exporting countries which account for over 25 percent of the world's agricultural exports. It is named after the city of Cairns, Australia where the first meeting was held. 
Agreements document would be written in Geneva at the end of $1993 .{ }^{100}$

The Final Act of the Uruguay Round partially resembled the earlier Dunkel Draft, but

Dunkel would not remain Director-General long enough to see it pass. The new Director-

General, Peter Sutherland, described the Final Act in the following way:

... not only is GATT alive and kicking, it will soon metamorphose into a vastly more important and expanded institution. My vision for this institution encompasses its role as defender of the rights of the weak and the vulnerable among its members; a place for tranquil reflection and resolution of problems in the trading systems; a voice of reason and equity in the din of clashing interests.

Changes made to the Final Act at Geneva would be minor, including changing the order of Articles IV and V, changing how the Director-General reported to committees, specifying the number of votes the EC would receive and other, smaller changes. More importantly, the Latinwritten sections on Dispute Settlement were included without any edits by outside parties. Latin diplomats, despite their earlier rivalries with the Group of Forty, were able to push the reform agenda through unaffected by outside influence. ${ }^{10102}$ The new Latin Dispute scheme would have the teeth that GATT had previously and severely lacked. As the body regulating world trade, disputes would be argued before a neutral panel of arbitrators who would review the dispute and rule against protectionist measures, this panel would be able to monitor compliance with decisions render and issue legally binding punishments to offenders, based on their level of noncompliance. ${ }^{103}$

The creation of the WTO amounted to a substantive reform of the GATT. No longer a mere agreement, the WTO became a treaty-level intergovernmental organization with regulatory

100 Bangkok Declaration Cairns Group. Geneva: GATT, 1993, 2

101 The Group of Forty was a rival power bloc to the Group of Ten in the Uruguay Round. Half it's members represented the East Asian nations at GATT.

102 Stiles, Kendall. "Negotiating Institutional Reform." Global Governance 2, no. 1 (1996): 119-48, 144

103 Ibid, 142 
oversight on its members; but how would the World Trade Organization fare in the ultimate political litmus test of ratification worldwide and within the US? ${ }^{104}$ Again, the US held an effective veto over the Uruguay Round Agreements because of its economic strength and the legitimacy that its membership afforded GATT.

In the 1990s the US was acting unilaterally as discussed previously, but in addition to the US stonewalling on agriculture and insisting on bilateral treaties the US was also pursuing regional trade agreements like Latin America had pursued during the 1970s and 1980s. The North American Free Trade Agreement was passed by the United States, Canada and Mexico in 1992 and entered into effect in 1994, making it contemporary with the final negotiations of the Uruguay Round. NAFTA was part of a US strategy to negotiate unilaterally in a more favorable environment and achieve its economic goals where multilateralism had failed. In this sense, US bilateral negotiations with Mexico allowed the US to bypass negotiating with a Latin bloc and instead divide and conquer individual nations. Neighboring nations were at least theoretically easy to negotiate with for the the US. Professor Jagdish Bhagwati of Columbia University described this process as:

a process by which a hegemonic power seeks (and often manages) to satisfy its multiple trade-unrelated demands on other, weaker trading nations more easily than through multilateralism. The persistence of free trade arrangements despite the success of the WTO must then be traced at least partly to an awareness of that reality. And, if this analysis has an element of truth to it, then free trade arrangements seriously damage the multilateral trade liberalization process by facilitating the capture of it by extraneous demands that aim, not to reduce barriers, but to increase them. ${ }^{105}$

The US would only succeed in convincing Mexico to enter NAFTA; Chile would refuse yet, the US was able to continue to create bilateral agreements outside the scope of GATT. The US could

104 Ibid, 146

105 Jagdish Bhagwati, and A. Krueger. "US Trade Policy: The Infatuation with Free Trade Areas." In The Dangerous Drift to Preferential Trade Agreements. Washington D.C.: AEI Press, 1995, 13-14 
not draw all of Latin America into NAFTA where it would have been much more efficient for the it to impose more unfair trade treaties.

In contrast to US regional ambitions, a left-wing populist, anti-US movement began in Latin America as a response to US economic pressures. Latin leaders like Hugo Chavez, Rafael Correa and Evo Morales led a movement of nationalization of industry and socialism that was a clear rejection of the Washington consensus. This occurred simultaneously with a growing change in Latin perceptions of US regional interests. Where the US had previously been the uncontested hegemonic leader of South America, China was beginning to fill in the gaps left behind. ${ }^{106}$

Resistance to US economic imperatives took many forms in different countries. In the Andes, coca leaves continued to be cultivated despite the US focus on the Drug War. President Hugo Chavez nationalized Venezuela's oil reserves and Evo Morales did the same for Bolivian natural gas. This rejection of neoliberalism did not aid in development in the long term, as the discovery of new reserves led to more dependence on fuel exports. Hal Weitzman, writer for the Financial Times, wrote that, "The resource nationalism of Chavez, Morales, and Correa sought to use oil and gas to pay for the mass redistribution of wealth, but in doing so, they made it likely that the money would run out sooner and tied their countries more closely to the notoriously volatile international commodity markets. ${ }^{107}$,

In NAFTA we can see another side of Mexico and Latin America's relationship with the US. While Latin American diplomats were capable of affecting institutional reform within the GATT, a large gulf in terms of political power continued to exist between the US and other

106 Hal Weitzman. Latin Lessons: How South America Stopped Listening to the United States and Started Prospering. New York: Wiley, 2011. 10

107 Hal Weitzman. Latin Lessons. New York: Wiley, 2011. 206-207 
American states. In the 1990s the US was influential enough to make multilateral agreements outside of GATT, to the dismay of those who hoped that the GATT and later the WTO would be the world's primary, and indeed, exclusive trade regulation body. Having the WTO be the sole arbitrator of world trade would reduce the amount of spaghetti bowl trade agreements, superfluous agreements that only complicate trade and drove up costs. ${ }^{108}$ Thus, the continued actions of the US in making trade deals outside of the GATT and WTO could be seen as a failure of Latin American GATT reform, as green room politics had been seen as an issue since the Tokyo Round, if not before.

The Latin response to US unilateralism was a return to economic form, as several Latin American leaders attempted to undo the changes to their states that were imposed by structural adjustment after the debt crisis. Leaders like Chavez, Correa and Morales attempted to return to the programs of ISI and nationalization that marked prior Latin American development schemes.

108 Akira Kotera. "What Is the "Spaghetti Bowl Phenomenon" of FTAs?" Research Institure of Economy, Trade and Industry. Accessed April 4, 2016. http://www.rieti.go.jp/en/columns/a01_0193.html. 


\section{Chapter 3:}

\section{Ratifying a Latin WTO Document}

As always, what would make or break the new WTO would be its reception by the US Senate. Given the tremendous political power of the US in creating or rejecting multilateral trade agreements, it cannot be understated how important the US role is. Here, in contrast to the Tokyo Round's political environment, the US Congress had grown increasingly wary of international trade deals and this resentment had been simmering since the Tokyo Round, if not earlier. Protectionist ideas are not new to the US, itself having extensively used the tariff throughout the $19^{\text {th }}$ century until Bretton Woods, from 1828 to the Tariff Act of 1930, more commonly referred to as the Smoot-Hawley Tariff Act. Ben Bernanke, former Chairman of the US Federal Reserve, described these policies, saying "Economists still agree that Smoot-Hawley and the ensuing tariff wars were highly counterproductive and contributed to the depth and length of the global Depression [1930s]."109

The usual protectionist sentiment motivating US politicians had been their accountability to their constituents, who fear that if the US signs multilateral trade agreements jobs will be lost to foreign competition. Another key issue had been the growing deficit in the US balance of trade in the late $20^{\text {th }}$ century, which means that the US was importing more goods than it was exporting, but many economists see these issues as functional parts of trade liberalization rather

109 Ben Bernanke. "Federal Reserve Board: Speech Bernanke, Monetary Policy and the Global Economy." Board of Governors of the Federal Reserve System. March 25, 2013. http://www.federalreserve.gov/newsevents/speech/bernanke20130325a.htm. 
than assaults on the US domestic economy. As the US developed after WWII, it was no longer necessary for it to be a manufacturing economy, instead it could become an information and service economy. Most economists would conclude that jobs lost in one part of the US had lead to gains in other areas for no net loss, or possibly overall gains in employment. The growth of the US balance of trade has been seen as a key characteristic of any mature capitalist economy, having switched from heavy manufacturing to information industries and services.

A political pundit at the time would have been smart to place money on the passage of the Uruguay Round Agreements Act, and it did indeed pass, but not without significant opposition. The trajectory of multilateral trade negotiations and arguably globalization would be challenged by consumer advocate Ralph Nader. Going back to the 1960s Ralph Nader had made a name for himself in US political discourse by advocating consumer protections and safety laws. Perhaps he was most famous for his work to expose the safety flaws in most car designs of the day. To Nader, the WTO represented a threat, not only to US sovereignty, but also to his legacy of consumer advocacy.

Nader took up his case against the GATT directly before the House of Representatives Small Business Committee in 1994 where he butted heads with Deputy US Trade Representative Rufus Yerxa on the merits of the Uruguay Round Agreements Act. In this committee meeting, Nader declared the WTO to be a threat to US sovereignty, democratic accountability, and Congressional ability to write legislation itself. Nader predicted that the WTO would be an unaccountable foreign bureaucracy working against the interests of the US. Specifically the WTO would "undermine citizen control and chill the ability of domestic democratic bodies to make decisions on a vast array of domestic policies from food safety to federal and state 
procurement to communications and foreign investment policies." This criticism directly addressed the idea of non-tariff barriers to the Uruguay Round. Furthermore, Nader held the new decision-making apparatus of the WTO in contempt, stating "[the WTO is] chronically secretive, non-participatory and not subject to any independent appeals process ... [and will] pull down our higher living standards." Rufus Yerxa countered this argument by claiming that the WTO would spur job growth in the US and add one to two hundred billion dollars to the US market each year. ${ }^{110}$

Nader's influence on this issue continued to grow, even influencing the main debates on the Uruguay Round Agreements Act itself. Senator Strom Thurmond (D-SC) submitted a packet of documents to the record as the Senate debated the Act, Among other dissenting materials were two articles written by Nader entitled Reject This Flawed Treaty and Brief Response to Some Senators Who Employ the Argument That the United States Can Always Get Out of the WTO on Six Months'Notice. Both articles lambasted the WTO for its lack of perceived transparency and its threat to US domestic issues. In particular, Nader worried about the voting scheme of the WTO, one of the key political achievements of Latin America. ${ }^{111}$ Nader was criticized by other Senators, notably Bob Dole, who dismissed Nader's claims by saying that the US was powerful enough to force the WTO into following US policy if it ruled against the US. ${ }^{112}$

The US ultimately passed the Uruguay Round Agreements Act on December 8, 1994 under President Clinton's fast-track authority with a 76 to 24 vote. ${ }^{113}$ This vote is noticeably

110 Mary Ann Akers. "Consumer, Labor Groups Denounce GATT." UPI. April 26, 1994.

111 Uruguay Round Agreements Act (Senate - December 1, 1994). Washington D.C.: US Government Printing Office, 1994, 137-139

112 Uruguay Round Agreements Act (Senate - December 1, 1994). Washington D.C.: US Government Printing Office, 1994, 231-232

113 David Sanger. "Senate Approves Trade Pact to Ease Trade Curbs - A Victory for Clinton." New York Times. December 2, 1994. 
different from the vote for the Tokyo Round Agreements almost twenty years prior in 1979 where that agreement passed by a much larger 90-4 margin. Clearly the protectionist interests within the US had a demonstrable effect on the votes in the Senate, but not enough to block the legislation. Clinton's fast-track power allowed for the submission of the bill without either the House or Senate being allowed to modify the bill. While the Executive Branch was happy with the bill's results, it had numerous opponents within Congress including Senators; Hollings (DSC), Dorgan (D-ND), Brown (R-CO), Wellstone (D-MN), Metzembaum (D-OH), Leahy (D-VT) and others. Senator Bob Dole and President Clinton agreed to establish a Review Commission that would allow the US to easily leave the WTO if its interests were threatened. ${ }^{114}$

Despite this resistance within the Senate and the smaller margin that the agreements passed by, the WTO entered into effect in the US and among other GATT contracting nations. The WTO itself is an impressively crafted agreement that, thanks to its Latin contributors among others, builds upon GATT and strengthens its weaknesses. Of particular importance is Article IX, Decision-Making, which clarifies how disputes will be settled. In the event that consensus cannot be reached, WTO members may vote on the issues, with a simple majority required for action. As each state gets one vote and developing nations far outnumber their wealthy counterparts, this is advantageous to Latin American economic goals. ${ }^{115}$

The Enabling Clause is reinforced within the WTO in Article XI of GATT $1994 .{ }^{116}$ Section two of Article XI grants Enabling Clause immunities to developing countries which are recognized as such by the United Nations, preventing further calls to remove countries from the

114 Uruguay Round Agreements Act (Senate - December 1, 1994). Washington D.C.: US Printing Office, 1994, 34 115 General Agreement on Tariffs and Trade. Geneva, 1994, 13

116 GATT 1994 is the GATT article that establishes the WTO, not the WTO Agreement itself. It is a legal stepping stone. 
Enabling Clause's aegis. ${ }^{117}$ This choice of having the UN decide who receives benefits is to Latin America's advantage because the UN is traditionally much more favorable to the interests of developing nations and this relieves pressures from within the WTO itself, largely from developed nations.

Furthermore, it is important to note that although the WTO does replace GATT, all prior legal precedents are carried over into the WTO. The WTO in Article XVI states that, “... the WTO shall be guided by the decisions, procedures and customary practices followed by the CONTRACTING PARTIES to GATT 1947 and the bodies established in the framework of GATT 1947." ${ }^{118}$ Both legally and bureaucratically, the WTO is an extension of GATT, rather than a replacement. This is a common misconception in the public discourse on the WTO, a misreading that historians of international economics should strive to correct even though GATT and by extension WTO legal language is often opaque.

Reactions to the WTO were largely positive among Latin American leaders, after all, they had achieved most of their major goals in decision making. Ecuador, who had never been a GATT member, readily joined the WTO in 1996 because Ecuador believed that the WTO would foster development. Ecuadorian Foreign Undersecretary of Economic Affairs Patricio Izurieta stated that, "... to open up the country, to be recognized in the international sphere. We are seeking world markets as the base for internal growth. ${ }^{119}$ " Other Latin American governments, including Chile and Uruguay were among the first nations to approve the WTO and become members. The new Director-General of the WTO, Peter Sutherland was optimistic about the

117 General Agreement on Tariffs and Trade. Geneva, 1994, 16

118 General Agreement on Tariffs and Trade. Geneva, 1994, 17

119 "A Three-Pronged Strategy for Trade." Wall Street Journal (New York), September 26, 1995, B16 sec. Accessed May 26, 2016. 
WTO's future, "[the WTO] binds nations in a global co-operative endeavor to raise incomes and create good jobs through fair and open trade. ${ }^{120}$

After ratification, it remained to be seen whether or not the new WTO would meet Latin American demands for development. As had been true under GATT, there would be a pause between the Uruguay Round's conclusion and the first WTO negotiations. The WTO Ministerial Conference began meeting periodically, roughly every two years to discuss trade issues. The first true WTO round began in 2001, aptly named the Doha Development Round or Doha Development Agenda. The Doha Development Round continues to the present day (2016), making it the longest round of negotiations in GATT/WTO history.

The creation of the WTO, now representing 162 nations, represents a historic turn in Latin American diplomacy. Through their negotiations in GATT, countries such as Brazil, Uruguay, Chile and other Latin American nations were able to change the rules that the world economy operated on. While the US still represented a hegemonic challenge to Latin developmental aspirations, this reversal of political power shows that through carefully choosing issues to advocate, coalition building and a shared economic vision, Latin American diplomats were able to challenge US hegemony and create meaningful change in a key international organization.

120 "Countries Rushing to Sign up for WTO GATT Successor's Launch Assured." Globe and Mail, December 30, 1994. Accessed May 26, 2016. http://ad4tq3gq5x.search.serialssolutions.com/?ctx_ver=Z39.882004\&ctx_enc=info:ofi/enc:UTF-

8\&rfr_id=info:sid/summon.serialssolutions.com\&rft_val_fmt=info:ofi/fmt:kev:mtx:journal\&rft.genre=article\&r $\mathrm{ft}$.atitle $=$ Countries rushing to sign up for WTO\&rft.jtitle $=$ The Globe and Mail (1936-Current)\&rft.date $=1994$ 12-30\&rft.issn=0319-0714\&rft.spage $=$ B2\&rft.externalDocID $=2336867822$ mdict=en-US. 


\section{Conclusion}

From the beginning of the $20^{\text {th }}$ century, Latin American nations have attempted to use membership in international organizations to further their development goal of protecting their economies, despite major structural barriers to these goals. One of the best organizations to observe Latin policy has been within the General Agreement of Tariffs and Trade. For many years, Latin diplomats struggled to find a voice within GATT to further their foreign policy while struggling with the developed nations who sought to monopolize world trade. Through cooperation with other organizations, like the UN, and other developing nations, like India, Latin America was able to begin reforming international trade law in the Tokyo Round of GATT (1973-1979). What Latin America gained in the round, specifically the Enabling Clause which gave Latin nations a degree of autonomy within a reciprocal system, was counterbalanced by unilateral action by both the United States and other developed nations.

Dissatisfied with the conclusion of the Tokyo Round, despite its legal significance, the Uruguay Round (1986-94) began before Latin America saw any benefits from their hard won rights. Even though the Group of Ten, led by Brazil and India, sacrificed much political capital in this resistance, the Latin nations were able to control the legal writing of what for them were the most important sections within the new World Trade Organization drafts, such as decision making and arbitration.

What remained to be seen was whether or not the WTO would correct the structural flaws 
of green room politics or non-tariff barriers mended during the Uruguay Round or would the patterns of behavior exhibited by the US and other developed nations continue into the foreseeable future. Because there was such a row during the Senate debate on approval, combined with media attention, the WTO became common knowledge in a way that the GATT had not been. This knowledge was much easier to disseminate, given the internet, which even in its early days was an effective means of mass communication. Some of the early WTO Ministerial Conferences were met with massive popular protests from protectionist political groups around the world. The most famous example was the disastrous 1999 Seattle WTO Ministerial, which saw an incredible turnout of tens of thousands of protestors from around the globe. Traditional American lobbying groups like the AFL-CIO, a coalition of labor unions, in cooperation with newer anti-globalization groups like Greenpeace, an environmentalist organization, affected a complete shutdown of the conference, with delegates being physically incapable of leaving their hotels. Further WTO Ministerial Conferences would continue to be dogged by popular protest well into the 2000s. ${ }^{121}$

The first real round of WTO negotiations would also be of dubious effectiveness for Latin American interests, being the longest round of negotiations in both GATT and WTO history. The Doha Development Round began in 2001 and was not concluded as of 2016 for a multitude of reasons. Once again Latin America, in a coalition led by Brazil and India, lead a policy drive to tackle non-tariff barriers, particularly in agriculture. Brazil moved to sue the US for dumping subsidized cotton exports onto the Brazilian market, undercutting the profits of Brazil's cotton and textile industries. Despite US resistance, the WTO ruled in Brazil's favor, declaring that the

121 Jeffrey Juris. Networking Futures: The Movements Against Corporate Globalization. Durham: Duke University Press, 2008. 48-51 
domestic subsidies of the US were a violation of its past commitments under GATT 1994 and that Brazil could use punitive tariffs against the US until it complied with the decision rendered. ${ }^{122}$ Brazil's cotton industry was reinforced by this decision and in 2016 Brazil is the fourth largest cotton producer, growing 2 million metric tons a year and it is also the second largest cotton exporter, behind the US, with 0.9 million metric tons of exports. ${ }^{123}$

This does beg an important question: if Latin diplomats can make such a demonstrable contribution to the creation of a system of world trade that aligns closely with Latin American developmental goals, why must Latin nations continue or need development? If this program of negotiating has been successful, why does such a disparity exist between the economies of the North and South? Many historians and economists have tried to explain the development gap between the US and Latin America, with multiple theories of development lag based on globalization, trade policy, domestic poverty, human resources and political instability. ${ }^{124}$

An optimistic economist would look solely at the GDP and find that for most of the past twenty years Latin America has experienced net GDP increase. ${ }^{125}$ This is an inherently flawed way to analyze Latin American success because it does not consider common social problems like wealth distribution that often come up in discussions of economics. There are many, better ways to look at Latin American development. In comparison to GDP gains among developed nations, Latin America has been falling behind ever since 1982, during the debt crisis. ${ }^{126}$ To break

122 "Dispute Settlement: Dispute DS267 United States - Subsidies on Upland Cotton." The World Trade Organization. Accessed May 17, 2016. https://www.wto.org/english/tratop_e/dispu_e/cases_e/ds267_e.htm

123 "World Cotton Production and Exports." Cotton Inc. May 2016. Accessed May 26, 2016. http://www.cottoninc.com/corporate/Market-Data/MonthlyEconomicLetter/pdfs/English-pdf-charts-andtables/World-Cotton-Production-Exp.pdf.

124 Francis Fukuyama. Falling Behind: Explaining the Development Gap Between Latin America and the United States. Oxford: Oxford University Press, 2008. 75

125 "GDP Growth (annual \%)." The World Bank Data. Accessed March 29, 2016. http://data.worldbank.org/indicator/NY.GDP.MKTP.KD.ZG/countries/xj?display=graph.

126 Ernesto Talvi. Think Tank 20: Growth, Convergence and Income Distribution: The Road from the Brisbane G- 
this down even further, Latin American nations have been evaluated using the convergence technique, which is a comparison of increases of GDP to increases in things commonly thought to promote development: human capital, infrastructure, public services, trade integration and innovation. While growth from 1950-2013 increased 22\% in this study, the factors of development remained stagnant. Clearly, the rewards of economic growth were not being shared with the majority of Latin American people. ${ }^{127}$ Thus, Ernesto Talvi of the Brookings Institute has written, “...income convergence was not associated either with a comparable convergence in key indicators of development. Fundamentally, the last was a decade of "development-less growth" in Latin America." 128

Regardless of the end results of economic development, the efforts of Latin American governments to reorganize the rules of world commerce on the principles of development and through creating the WTO represents a historic turn in the diplomatic success of these countries. While this victory was negotiated and its battles chosen carefully, such as the choice to focus on decision making at the expense of TRIPs and TRIMs in the Uruguay Round, it demonstrates the efficacy of the Latin American region in multilateral negotiations.

There is no single answer to the monolithic question of development which defines not only the $20^{\text {th }}$ century, but certainly also the beginning of the $21^{\text {st }}$. What this history of negotiations does mean is that the nations of Latin America should be considered plainly for what they are, states effectively pursuing specific foreign policy objectives and economic development goals and to some extent succeeding.

20 Summit: Latin America's Decade of Development-less Growth. Washington D.C.: Brookings Institute, 2013, 36

127 Talvi, Ernesto. Latin America's Decade of Development-less Growth. Washington D.C.: Brookings Institute, 2013, 39

128 Ibid. 40 


\section{Bibliography}

"The 128 Countries That Had Signed GATT by 1994." WTO | GATT Members. 2015. Accessed October 16, 2015.

"A Three-Pronged Strategy for Trade." Wall Street Journal (New York), September 26, 1995, B16 sec. Accessed May 26, 2016.

Accession of Mexico. Geneva: GATT, 1979.

Act of Bogota: Measures for Social Improvement and Economic Development Within the Framework of Operation Pan America. Washington, D.C.: Pan American Union, 1961. Agenda Item 1. Measures for the Expansion of Trade of Developing Countries as a Means of Furthering Their Economic Development. Geneva: GATT, 1963.

Akers, Mary Ann. "Consumer, Labor Groups Denounce GATT." UPI. April 26, 1994. Bangkok Declaration Cairns Group. Geneva: GATT, 1993.

Bernanke, Ben. "Federal Reserve Board: Speech Bernanke, Monetary Policy and the Global Economy." Board of Governors of the Federal Reserve System. March 25, 2013. http://www.federalreserve.gov/newsevents/speech/bernanke20130325a.htm.

Bhagwati, Jagdish and A. Krueger. "US Trade Policy: The Infatuation with Free Trade Areas." In The Dangerous Drift to Preferential Trade Agreements. Washington D.C.: AEI Press, 1995.

Central American Common Market. Geneva: GATT, 1970. 
Communication from Mexico Conditional List of Offers of Mexico Revision. Geneva: GATT, 1992.

Consultative Group of Eighteen Third Meeting 22-23 June 1976 Memorandum from the Brazilian Delegation on the Improvement of the International Framework for Trade. Geneva: GATT, 1976.

"Countries Rushing to Sign up for WTO GATT Successor's Launch Assured." Globe and Mail, December 30, 1994. Accessed May 26, 2016. http://ad4tq3gq5x.search.serialssolutions.com/?ctx_ver=Z39.882004\&ctx_enc=info:ofi/enc:UTF8\&rfr_id=info:sid/summon.serialssolutions.com\&rft_val_fmt=info:ofi/fmt:kev:mtx:journ al\&rft.genre $=$ article\&rft.atitle $=$ Countries rushing to sign up for WTO\&rft.jtitle $=$ The Globe and Mail (1936-Current)\&rft.date=1994-12-30\&rft.issn=03190714\&rft.spage $=\mathrm{B} 2 \&$ rft.externalDocID $=2336867822$ mdict $=$ en-US.

Convenio De Panama Constitutivo Del Sistema Economico Latinoamericano (SELA). Caracas: SELA, 1975.

C.R. Neu and Emery Simon. U.S. Trade Policy and the Tokyo Round of Multilateral Trade Negotiations. Washington D.C.: GPO, 1979.

Customs Unions and Free-Trade Areas - Latin American Free Trade Association: Statement by the Representative of Peru at the Council Meeting of 12 February 1970. Geneva: GATT, 1970.

Differential and More Favourable Treatment of Developing Countries in the GATT Dispute Settlement System Note by the Secretariat Revision. Geneva: GATT, 1988. 
“Dispute Settlement: Dispute DS267 United States - Subsidies on Upland Cotton.” The World Trade Organization. Accessed May 17, 2016. https://www.wto.org/english/tratop_e/dispu_e/cases_e/ds267_e.htm

Evaluation On The Situation Of The Uruguay Round: Communication from the Permanent Representative of Uruguay on Behalf of SELA. Geneva: GATT, 1990.

Expansion of International Trade: Note Submitted by the Less-developed Countries. Geneva: GATT, 1959.

Felix, David. "Latin America's Debt Crisis." World Policy Journal 7, no. 4 (1990): 733-71.

Fukuyama, Francis. Falling Behind: Explaining the Development Gap Between Latin America and the United States. Oxford: Oxford University Press, 2008.

Gardner, Richard N. Sterling-Dollar Diplomacy. New York: McGraw Hill, 1956.

"GDP Growth (annual \%)." The World Bank Data. Accessed March 29, 2016. http://data.worldbank.org/indicator/NY.GDP.MKTP.KD.ZG/countries/xj?display=graph .

General Agreement on Tariffs and Trade. Geneva, 1986.

General Agreement on Tariffs and Trade. Geneva, 1994.

General Agreement of Tariffs and Trade: Tokyo Declaration on Multilateral Trade Negotiations Ministerial Meeting Tokyo, 12-14 September 1973 Declaration. Geneva: GATT, 1973. General Agreement on Tariffs and Trade (GATT) Punta del Este Declaration. Geneva: GATT, 1984.

Harrison, Glenn, Rutherford, Thomas and Tarr, David G. "Quantifying the Uruguay Round.” In Will Martin and L. Alan Winters, eds, The Uruguay Round and the Developing Countries. Cambridge: Cambridge University Press, pp. 183-215, Table 8.7 
Helleiner, Eric. Forgotten Foundations of Bretton Woods: International Development and the Making of the Postwar Order. New York: Cornell University Press, 2014.

Improvements to the GATT Dispute Settlement Rules and Procedures Decision of 12 April 1989. Geneva: GATT, 1989.

Improvement of World Trade Relations Through the Implementation of the Work Programme of GATT. Geneva: GATT, 1984.

Irwin, Douglas Mavroidis, Petros and Sykes, Alan. The Genesis of the GATT. New York, NY: Cambridge University Press, 2008.

Juris, Jeffrey. Networking Futures: The Movements Against Corporate Globalization. Durham: Duke University Press, 2008.

Kirshner, Orin. ed. The Bretton Woods-GATT System: Retrospect and Prospect After Fifty Years. Armonk, New York: M. E. Sharpe, 1996.

Korinek, Anton. “Hot Money and Serial Financial Crises.” IMF, 2010.

Kotera, Akira. "What Is the "Spaghetti Bowl Phenomenon" of FTAs?" Research Institure of Economy, Trade and Industry. Accessed April 4, 2016. http://www.rieti.go.jp/en/columns/a01_0193.html.

Long, Russel B. "S.1376 — 96th Congress (1979-1980)." Congress.gov. Accessed March 9, 2016. https://www.congress.gov/bill/96th-congress/senate-bill/1376.

Meeting at Ministerial Level Brussels, December 1990 CUBA Statement by H.E. Mr. Alberto Betancourt Roa, Deputy Minister of Foreign Trade. Geneva: GATT, 1990.

"Misunderstood Moderate; Raul Prebisch." The Economist, March 7, 2009, 78.

Multilateral Trade Negotiations Groups “Tropical Products” Points Made by Delegations with 
Respect to Negotiations on Tropical Products. Geneva: GATT, 1975.

New Negotiating Structure and Chairmen Agreed in TNC. Geneva: GATT, 1991.

Participation of the Developing Countries in the Multilateral Trade Negotiations. Geneva:

GATT, 1974.

Prebisch, Raul. "Hace una teoria de la transformacion.” Revista de la CEPAL, December 2008, $27-71$

Proposal by Mexico for Formulating a Special Negotiating Procedure in Accordance with Paragraph 10 of the Tokyo Declaration, for Developing Countries, in Respect of the Elimination of Quantitative Restrictions. Geneva: GATT, 1975.

Resolution Adopted by the General Assembly 3201 (S-VI). Declaration on the Establishment of a New International Economic Order. New York: United Nations, 1974.

Sanger, David. "Senate Approves Trade Pact to Ease Trade Curbs - A Victory for Clinton." New York Times. December 2, 1994.

Special and More Favourable Treatment for Developing Countries Statement Made by the Delegation of the Commission of the European Communities at the Group "Tariffs" Meeting, December 1976. Geneva: GATT, 1976.

Special and More Favourable Treatment for Developing Countries Statement Made by the Delegation of Japan at the Group "Tariffs" Meeting, December 1976. Geneva: GATT, 1976.

Special and More Favourable Treatment for Developing Countries Statement Made by the United States Delegation at the Group “Tariffs” Meeting, December 1976. Geneva: GATT, 1976. 
Special and More Favourable Treatment Reciprocity and Fuller Participation of Developing Countries Decision of 28 November 1979. Geneva: GATT, 1979.

Spoor, Max. Two Decades of Adjustment and Agricultural Development in Latin America and the Caribbean. Economic Commission on Latin America and the Caribbean, LC/L. 1352, 2000.

Stiles, Kendall. "Negotiating Institutional Reform: The Uruguay Round, the GATT, and the WTO." Global Governance 2, no. 1 (1996): 119-48

Srinivasan, T.N.. Developing Countries and the Multilateral Trading System: From GATT to the Uruguay Round and the Future. Boulder: Westview Press, 1998.

Stiglitz, Joseph. Globalization and Its Discontents. New York, NY: W.W. Norton \& Company, 2002.

Talvi, Ernesto. Think Tank 20: Growth, Convergence and Income Distribution: The Road from the Brisbane G-20 Summit: Latin America's Decade of Development-less Growth. Washington D.C.: Brookings Institute, 2013.

Tandon, Yash, ed. Paved with Good Intentions: Background to the GATT, Uruguay Round and WTO. Harare: Seatini, 2004, 35-36

Trade Negotiations Committee: Twenty-first Meeting: 13 January 1992. Geneva: GATT, 1992. Trends and Developments in International Commodity Trade: Report by the Contracting Parties' Nominee as Chairman of the Interim Co-ordinating Committee for International Commodity Arrangements (ICCICA) to the Contracting Parties to the General Agreement on. Geneva, 1958.

UNCTAD Resolutions on the Generalized System of Preferences. Geneva: GATT, 1975. 
Uruguay Round Agreements Act (Senate - December 1, 1994). Washington D.C.: US Government Printing Office, 1994.

Wallach, Lori and Patrick Woodall. Whose Trade Organization? New York, New York: New Press, 2004.

Weitzman, Hal. Latin Lessons: How South America Stopped Listening to the United States and Started Prospering. New York: Wiley, 2011.

Wilcox, Clair. A Charter for World Trade. New York, NY: Macmillan, 1949.

Wilson, Woodrow. Address of President Woodrow Wilson Delivered before the Southern Commercial Congress Held at Mobile, Ala, October 27, 1913. Washington D.C.: GPO, 1913.

Winham, Gilbert. "Gatt and the International Trade Regime." International Journal 45, no. 3 (1990): 796-822.

"World Cotton Production and Exports." Cotton Inc. May 2016. Accessed May 26, 2016. http://www.cottoninc.com/corporate/Market-Data/MonthlyEconomicLetter/pdfs/Englishpdf-charts-and-tables/World-Cotton-Production-Exp.pdf. 